\title{
Morphological, Physiological and Molecular Markers for Salt-Stressed Plants
}

\author{
Aigerim Soltabayeva ${ }^{1, * \mathbb{D}}$, Assel Ongaltay ${ }^{1}$, John Okoth Omondi ${ }^{2}$ and Sudhakar Srivastava ${ }^{3}$ \\ 1 Biology Department, School of Science and Humanities, Nazarbayev University, Nur Sultan Z05H0P9, \\ Kazakhstan; assel.ongaltay@nu.edu.kz \\ 2 International Institute of Tropical Agriculture, PO Box 30258 Lilongwe 3, Malawi; okoth05@gmail.com or \\ jo.omondi@cgiar.org \\ 3 Beijing Advanced Innovative Center For Tree Breeding by Molecular Design, Beijing Forestry University, \\ No. 35, Qinghua East Road, Beijing 100083, China; srivastavasudhakar@gmail.com \\ * Correspondence: aigerim.soltabayeva@nu.edu.kz
}

Citation: Soltabayeva, A.; Ongaltay, A.; Omondi, J.O.; Srivastava, S. Morphological, Physiological and Molecular Markers for Salt-Stressed Plants. Plants 2021, 10, 243. https:// doi.org/10.3390/plants10020243

Academic Editor: Igor Kovalchuk Received: 18 November 2020 Accepted: 31 December 2020 Published: 27 January 2021

Publisher's Note: MDPI stays neutral with regard to jurisdictional clai$\mathrm{ms}$ in published maps and institutional affiliations.

Copyright: $(\odot 2021$ by the authors. Licensee MDPI, Basel, Switzerland. This article is an open access article distributed under the terms and conditions of the Creative Commons Attribution (CC BY) license (https:// creativecommons.org/licenses/by/ $4.0 /)$.

\begin{abstract}
Plant growth and development is adversely affected by different kind of stresses. One of the major abiotic stresses, salinity, causes complex changes in plants by influencing the interactions of genes. The modulated genetic regulation perturbs metabolic balance, which may alter plant's physiology and eventually causing yield losses. To improve agricultural output, researchers have concentrated on identification, characterization and selection of salt tolerant varieties and genotypes, although, most of these varieties are less adopted for commercial production. Nowadays, phenotyping plants through Machine learning (deep learning) approaches that analyze the images of plant leaves to predict biotic and abiotic damage on plant leaves have increased. Here, we review salinity stress related markers on molecular, physiological and morphological levels for crops such as maize, rice, ryegrass, tomato, salicornia, wheat and model plant, Arabidopsis. The combined analysis of data from stress markers on different levels together with image data are important for understanding the impact of salt stress on plants.
\end{abstract}

Keywords: salinity stress; stress tolerance; morphological markers; physiological markers; chlorophyll; antioxidant; molecular markers

\section{Introduction}

Growth and development of plants are affected by various stresses. Salinity is one of the major abiotic stress which adversely affects the overall growth and yield of crops [1-3]. It is estimated that $>1$ billion ha of the world land is salinized [4] and continued salinization of the ever-decreasing agricultural land further exacerbates food insecurity as human population surges. Some of the major world crops such as maize, wheat, rice, tomato and sunflower are reviewed here where, salinity resulted in the reduction of the yield [2,5-8]. The compromised performance causing poor yield could be due to the reduction in photosynthesis efficiency, chlorophyll, total protein, biomass, stomata closure and increasing the oxidative stress [9].

To improve productivity in salt-affected soils, selection and adoption of plant varieties with high salt tolerance has always been a preferred choice $[10,11]$. This selection is based on morphological, physiological and molecular markers. Among morphological markers, root or shoot morphology, visible early senescence, biomass of grains is some of the important parameters that are considered. Physiological and biochemical markers examine chlorophyll content, accumulation of proline, sucrose, stress protectants, membrane stability and hormones content $[9,12]$. These physiological markers, especially hormonal, polyamine and proline changes in plants are important to increase salt tolerance of plants. For example, such can be boosted by exogenous treatments with hormones, glycine betaine, proline, polyamines, paclobutrazol, nanoparticles [13]. The molecular markers include salt 
stress tolerant genes, transcription factors, metabolic pathway related genes [9,12]. These molecular markers have led to significant progress in genetic engineering of plants with salt tolerance [9]. Altogether, all stress markers in plants help in identification of specific genes involved in salt tolerance [9].

The advent of information technology (IT), especially different smart data analysis techniques which are being applied in other fields, are also directed towards the improvement of agriculture. These used techniques are known as machine learning - a subset of artificial intelligence. Machine learning algorithms build a model based on data samples, called "training data," developed in order to make predictions or decisions without being explicitly programmed to do so [14]. Deep learning is a machine learning method based on artificial neural networks with multiple hidden layers and representation learning [15]. Deep learning architectures have been applied to various fields including agriculture, bioinformatics, drug design, medical image analysis, among others, where they predict results with a given data set and have produced comparable results and, in some cases, surpassing performance of human experts [15-17]. Deep learning algorithms such as Convolutional Neural Networks (CNN), Recurrent Neural Networks (RNN), Long Short-Term Memory (LSTM) are frequently applied for prediction and/or detection, quantification of biotic stresses in plant leaves $[17,18]$. They are used for screening stress tolerant or sensitive genotypes by using the morphological characteristics of plants through recorded images [19]. Few of these studies are related to abiotic stress, for example drought [20-22] and salinity [19]. This evaluation and prediction of stress impact on plants by deep learning approaches give additional agricultural solutions to prevent the risk of yield losses through abiotic or biotic stresses. Thus, they have a big potential in developing smart greenhouse or field production. However, this approach primarily records morphological markers as it only analyzes the image-type data. This limits the applicability of IT in rigorous salinity studies and necessitates the knowledge of additional markers that can explain the mechanism at molecular level. Different salinity stress markers in plants at physiological, metabolic, protein and molecular levels result in near-conclusive understanding of the salinity effects, challenges and solutions. Therefore, this review focuses on elaborating advances in salinity stress markers that lead to recognition of salt stress in plants at morphological, physiological and molecular level, as well as on early detection methods and salinity stress symptoms that are commonly used in the plant biology research community.

\section{Detection of Salinity Stress}

\subsection{Morphological Markers}

Salt concentrations in soils vary from one place to another and that affects the growth of plants depending on the concentration [12]. Generally, $\mathrm{NaCl}$ salt is commonly used for salt stress studies [12] and in this review we focused on $\mathrm{NaCl}$ induced stress signs in plants. The stress effects on morphology are manifested by different means such as dry or fresh total biomass, plant height and through other morphological markers [23-25]. Generally, an increase of salt content in the growing environment increases the impact of salt stress on plant growth (Figure 1). This response varies from plant to plant [12]. In Arabidopsis, wheat, maize, rice and rye grass, the decrease of total plant biomass was observed at 100-150 mM NaCl levels, while in tomato and sunflower, the weight decreased on $50 \mathrm{mM}$ $\mathrm{NaCl}$ application (Figure 1). Studies on salinity effect on trees are scarce, even though they too are affected by salinity, in citrus and acacia, a $100 \mathrm{mM} \mathrm{NaCl}$ caused biomass changes (decrease of 13\% and 15\%, respectively) at early stages of growth [26-28], however, palm was less susceptible as it experienced growth changes (biomass did not decrease) at severe salt stress levels [29]. Despite the differences observed in biomasses in response to salinity levels, the growth of all these plants were significantly repressed by 200-300 mM salt $(\mathrm{NaCl})$ treatment [30-36]. Conversely, these salt concentrations did not affect the growth of halophyte plants such as salicornia (Figure 1). However, above $400 \mathrm{mM} \mathrm{NaCl}$, the yield of a salicornia is also decreased [37-40]. 


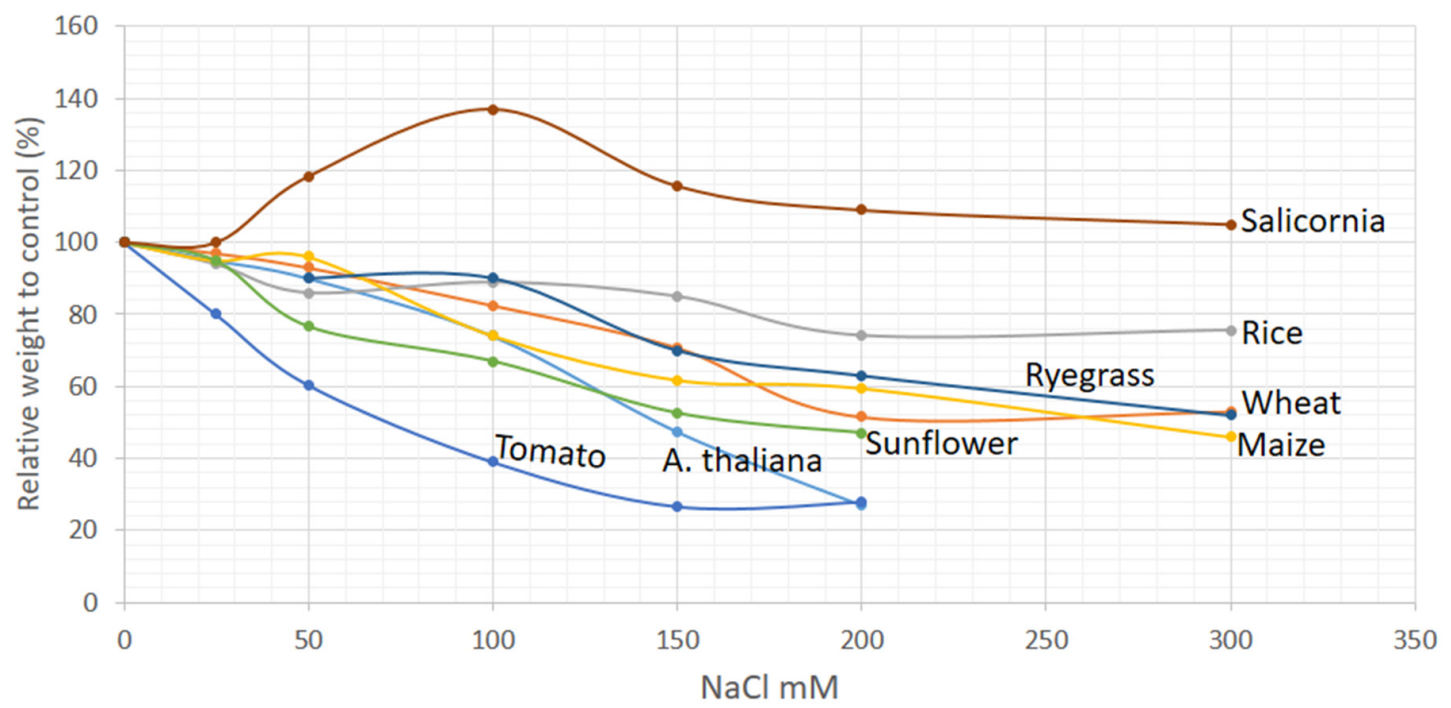

Figure 1. Effect of salinity level on relative biomass changes in crop plants. The relative dry weight compared to control was used as a growth parameter. The irrigation of soil by saline water $(\mathrm{NaCl})$ from $0-300 \mathrm{mM}$ was used salt application. Sources of the data were: A. thaliana: [25,32,41,42], wheat: (Triticum aestivum) [30,36,43,44], rice (Oryza sativa): [31,33], maize (Zea mays): [24,34,45-47], tomato: (Solanum lycopersicum): [35,48,49], sunflower: (T Helianthus annutis): [50-52], ryegrass (Lolium perenne): [53], salicornia: [37-39].

Salinity stress also affects germination rate of seeds and thus germination is also an informative marker for salinity stress. Since germination is among the foremost morphological processes, it is a useful indicator of stress as compared to biomass as stress can be known as early as 2-14 days depending on a plant species. The germination rate of Arabidopsis, sunflower and tomato declined by $71 \%, 62 \%$ and $35 \%$, respectively at $100 \mathrm{mM}$ $\mathrm{NaCl}$ (Figure 2). The germination percentage of wheat, maize and rice declined significantly at higher salinity level (200 mM) compared to biomass changes (Figures 1 and 2). At $400 \mathrm{mM} \mathrm{NaCl}$, salinity stress is critical and most crops do not germinate, although below this concentration, some plants such as wheat can have $3 \%$ germination rate with a retarded growth (Figures 1 and 2). Thus, the growth markers in plants are sensitive to salt stress at 100-400 $\mathrm{mM} \mathrm{NaCl}$.

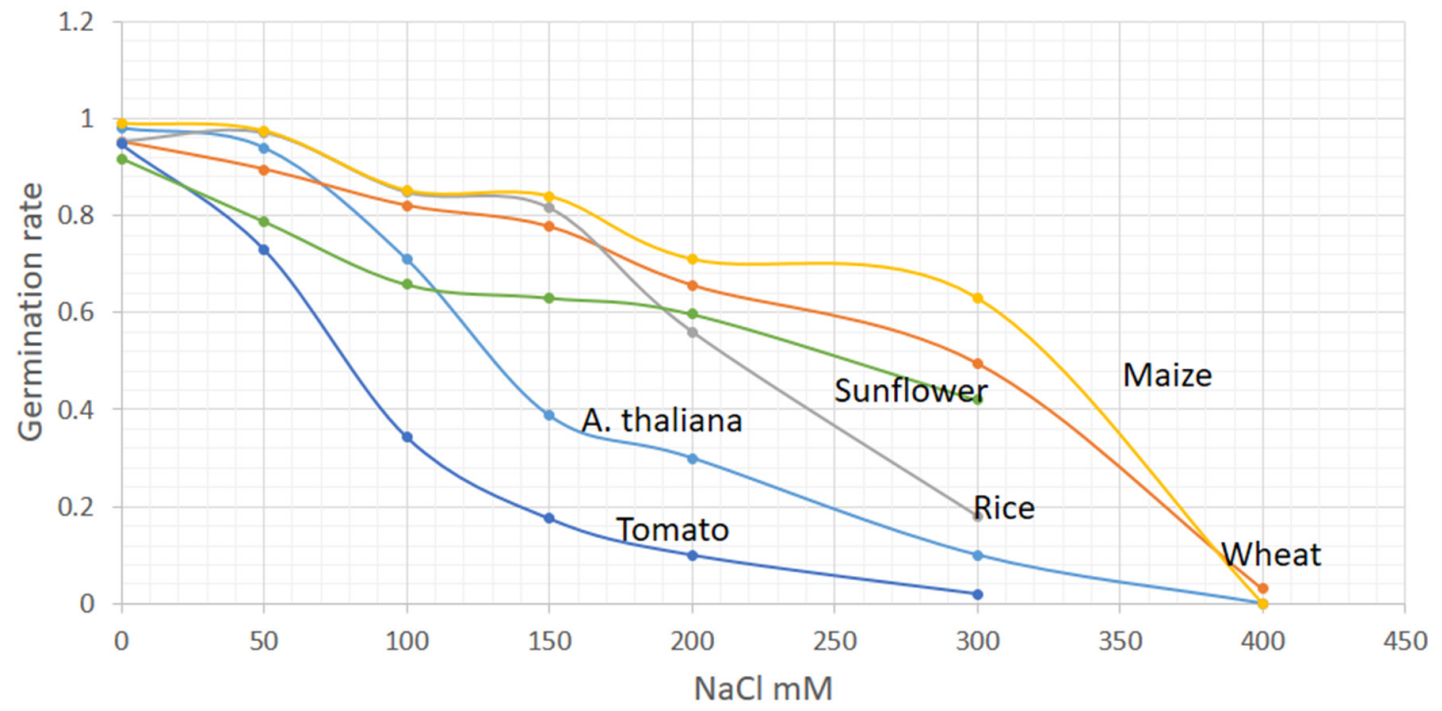

Figure 2. Changes in germination rate of crop plants at different levels of salt stress. Germination rate after 7 days plants grown under different level of $\mathrm{NaCl}$ concentration. Data presented for A. thaliana [54-57], wheat (Triticum aestivum) [24,47,58,59], rice (Oryza sativa) [31,60], maize (Zea mays) [46,61,62], tomato (Solanum lycopersicum) [63-65], sun flower (T Helianthus annutis) [50,66], salicornia [39,67]. 
In addition to total plant biomass changes, the weight of shoot, root and leaves are frequently used for evaluation of salt stress [12]. The length of roots and shoots, root architecture and the number of secondary branches on them, diameter of shoot, the tiller numbers, leaves number are used as growth parameters in salinity $[23,26,34,35,42,44,45,47,68,69]$. Generation rate of young leaves is also used for analysis of salinity impact [12,32]. Besides the growth parameters, the flowering time may show the effect of salt stress on the reproductive stage of plants. In Arabidopsis, wheat, barley, maize and rice the flowering is delayed under salinity stress [70-77].

\subsection{Physiological Markers}

Measurement of $\mathrm{Na}^{+}$or $\mathrm{Cl}^{-}$ions concentration in the leaves and roots reflect salinity stress in plants (Table 1). Measurement of potassium ion $\left(\mathrm{K}^{+}\right)$content and/or ratio of $\mathrm{K}^{+} / \mathrm{Na}^{+}$are also frequently used (Table 1 ). In addition, ratios of other ions such as $\mathrm{Na}^{+} / \mathrm{Ca}^{2+}, \mathrm{Ca}^{2+} / \mathrm{Mg}^{2+}$ and $\mathrm{Cl}^{-} / \mathrm{NO}_{3}{ }^{-}$are usually evaluated as they influence nutrient uptake [12]. Increase of other salts in the soil in addition to available $50-100 \mathrm{mM} \mathrm{NaCl}$ alters the intracellular concentration of salt $\left(\mathrm{Na}^{+}\right.$and $\left.\mathrm{Cl}^{-}\right)$in Arabidopsis, wheat, rice and maize $[23,24,32,68,78]$.

Salinity stress decreases photosynthesis process [12]. This is evident by monitoring stomatal conductance, chlorophyll fluorescence and chlorophyll contents $[12,79]$. The decrease in chlorophyll content was observed under $50 \mathrm{mM}-250 \mathrm{mM}$ salt application in major crop plants (Table 1). The osmotic parameters of plant changes rapidly in response to salt stress [12]. This is usually expressed by evaluating the changes in turgor pressure, osmotic pressure, RWC and water potential $[33,37,39,78]$. For example, water potential in Arabidopsis decreases upon treatment with $100 \mathrm{mM} \mathrm{NaCl}$ (Table 1). Another way of evaluating osmotic changes occurring during salinity stress is the measurement of osmolytes such as sucrose, proline, glycine-betaine. These osmolytes are stress protectors and their accumulation in plants experiencing salinity stress is an adaptive mechanism [12]. Sucrose and proline normally increase in salinity levels of 75-200 mM, however, this varies among plants; for example, in Arabidopsis, wheat and rice it is at $75-200 \mathrm{mM} \mathrm{NaCl}$ application, while in maize it is at $100 \mathrm{mM}$ [32-34,80-82].

Table 1. Range of changes of the physiological parameters depend on time and concentration of $\mathrm{NaCl}$ application.

\begin{tabular}{|c|c|c|c|c|c|c|c|c|}
\hline \multirow{2}{*}{$\begin{array}{c}\text { Physiological } \\
\text { Parameters }\end{array}$} & \multicolumn{2}{|c|}{ Salt Sensitive Plants } & \multicolumn{5}{|c|}{ Less Salt Sensitive Plants } & \multirow{2}{*}{$\begin{array}{l}\text { Halophyte } \\
\text { Salicornia }\end{array}$} \\
\hline & Tomato & A.Thaliana & Rice & Maize & Wheat & Sunflower & Ryegrass & \\
\hline $\begin{array}{l}\text { Na content } \\
\text { increase }\end{array}$ & $\begin{array}{c}50-100 \mathrm{mM} ; \\
1 \mathrm{~d}\end{array}$ & $\begin{array}{l}100 \mathrm{mM} ; \\
4 \mathrm{~h}-1 \mathrm{~d}\end{array}$ & $\begin{array}{l}100 \mathrm{mM} ; \\
6 \mathrm{~h}-7 \mathrm{~d}\end{array}$ & $100 \mathrm{mM} ; 21 \mathrm{~d}$ & 100 mM; 3 d & $\begin{array}{l}100-150 \mathrm{mM} ; \\
1 \mathrm{~d}\end{array}$ & $\begin{array}{l}100-250 \mathrm{mM} ; \\
4 \mathrm{~d}\end{array}$ & $\begin{array}{c}100-200 \mathrm{mM} ; \\
10-42 \mathrm{~d}\end{array}$ \\
\hline $\begin{array}{l}\text { K content } \\
\text { decrease }\end{array}$ & $\begin{array}{c}50-100 \mathrm{mM} ; \\
1 \mathrm{~d}\end{array}$ & $100 \mathrm{mM} ; 4 \mathrm{~h}$ & 100 mM; 7 d & - & $\begin{array}{l}75-100 \mathrm{mM} ; \\
7-42 \mathrm{~d}\end{array}$ & 100 mM; $1 \mathrm{~d}$ & $\begin{array}{l}\text { 100-250 mM; } \\
4 \mathrm{~d}\end{array}$ & $\begin{array}{c}100-200 \mathrm{mM} ; \\
10-42 \mathrm{~d}\end{array}$ \\
\hline $\begin{array}{c}\text { RWC * } \\
\text { decrease }\end{array}$ & $100 \mathrm{mM} ; 2 \mathrm{~h}$ & $\begin{array}{c}100-200 \mathrm{mM} ; \\
1-15 \mathrm{~d}\end{array}$ & $\begin{array}{l}100 \mathrm{mM} ; \\
4-12 \mathrm{~h}\end{array}$ & $50 \mathrm{mM} ; 7 \mathrm{~d}$ & $\begin{array}{c}75-100 \mathrm{mM} \\
\text { 3-42 d }\end{array}$ & $\begin{array}{c}50-100 \mathrm{mM} ; \\
2-54 \mathrm{~d}\end{array}$ & $\begin{array}{c}200-250 \mathrm{mM} ; \\
12-14 \mathrm{~d}\end{array}$ & $\begin{array}{c}100-200 \mathrm{mM} ; \\
10-42 \mathrm{~d}\end{array}$ \\
\hline $\begin{array}{c}\text { Chlorophyll } \\
\text { decrease }\end{array}$ & $\begin{array}{c}75-100 \mathrm{mM} \\
3 \mathrm{~d}\end{array}$ & $\begin{array}{c}\text { 100-200 mM; } \\
\text { 4-18 d }\end{array}$ & $\begin{array}{c}30-150 \mathrm{mM} ; \\
6 \mathrm{~h}-3 \mathrm{~d}\end{array}$ & $50 \mathrm{mM} ; 21 \mathrm{~d}$ & $\begin{array}{c}50-100 \mathrm{mM} ; \\
3-42 \mathrm{~d}\end{array}$ & $\begin{array}{l}100 \mathrm{mM} ; \\
40-60 \mathrm{~d}\end{array}$ & $250 \mathrm{mM} ; 14 \mathrm{~d}$ & $\begin{array}{c}85-250 \mathrm{mM} ; \\
14-30 \mathrm{~d}\end{array}$ \\
\hline $\begin{array}{l}\text { Electrolyte } \\
\text { leakage } \\
\text { increase }\end{array}$ & $\begin{array}{c}50-100 \mathrm{mM} ; \\
1 \mathrm{~d}\end{array}$ & $\begin{array}{l}100 \mathrm{mM} ; \\
6 \mathrm{~h}-15 \mathrm{~d}\end{array}$ & $100 \mathrm{mM} ; 6 \mathrm{~h}$ & $100 \mathrm{mM} ; 8 \mathrm{~d}$ & $100 \mathrm{mM} ; 30 \mathrm{~d}$ & 100 mM; 2 d & $\begin{array}{c}100-250 \mathrm{mM} \\
12-14 \mathrm{~d}\end{array}$ & - \\
\hline $\begin{array}{l}\text { Stomatal } \\
\text { conductance } \\
\text { decrease }\end{array}$ & $\begin{array}{l}100 \mathrm{mM} ; \\
7-12 \mathrm{~d}\end{array}$ & $100 \mathrm{mM} ; 15 \mathrm{~d}$ & $100 \mathrm{mM} ; 30 \mathrm{~d}$ & $60 \mathrm{mM} ; 12 \mathrm{~h}$ & $\begin{array}{l}100 \mathrm{mM} ; \\
7-21 \mathrm{~d}\end{array}$ & $\begin{array}{c}50-100 \mathrm{mM} \\
5-35 \mathrm{~d}\end{array}$ & - & - \\
\hline $\begin{array}{c}\text { Water } \\
\text { potential }\end{array}$ & $100 \mathrm{mM} ; 2 \mathrm{~h}$ & $100 \mathrm{mM} ; 4 \mathrm{~d}$ & $100 \mathrm{mM} ; 48 \mathrm{~h}$ & $60 \mathrm{mM} ; 20 \mathrm{~d}$ & $\begin{array}{l}100 \mathrm{mM} ; \\
5-70 \mathrm{~d}\end{array}$ & $\begin{array}{c}25-100 \mathrm{mM} ; \\
1-54 \mathrm{~d}\end{array}$ & - & $\begin{array}{c}150-400 \mathrm{mM} ; \\
24-42 \mathrm{~d}\end{array}$ \\
\hline $\begin{array}{l}\text { Proline } \\
\text { increase }\end{array}$ & - & $\begin{array}{l}100 \mathrm{mM} ; \\
14-15 \mathrm{~d}\end{array}$ & - & $50 \mathrm{mM} ; 1 \mathrm{~d}$ & $\begin{array}{c}50-100 \mathrm{mM} ; \\
7-42 \mathrm{~d}\end{array}$ & $\begin{array}{c}100-150 \mathrm{mM} ; \\
7-15 \mathrm{~d}\end{array}$ & - & $\begin{array}{c}85-600 \mathrm{mM} ; \\
30-45 \mathrm{~d}\end{array}$ \\
\hline $\begin{array}{l}\text { Glycine } \\
\text { betaine } \\
\text { increase }\end{array}$ & - & - & - & $50 \mathrm{mM} ; 21 \mathrm{~d}$ & - & $100 \mathrm{mM} ; 7 \mathrm{~d}$ & - & $\begin{array}{c}200-500 \mathrm{mM} ; \\
15 \mathrm{~d}\end{array}$ \\
\hline Reference & [83-86] & [87-91] & {$[92,93]$} & [94-97] & [98-102] & [103-106] & {$[107,108]$} & [109-111] \\
\hline
\end{tabular}

${ }^{*} \mathrm{RWC}=$ relative water content; $\mathrm{h}=$ hours; $\mathrm{d}=$ days. 


\subsection{Oxidative Stress Markers}

Salinity stress causes imbalance of reactive oxygen species [112]. This imbalance is mainly as a consequence of disruption of electron transport chains (ETC) during photoinhibition and/or decrease in water potential [113]. The ROS is dramatically increased upon salinity stress and the first ROS reaction is termed as "oxidative burst" [114]. The higher level of ROS becomes toxic for cells resulting in cellular damages and may lead to its death, if increase is unchecked. Moreover, ROS also acts as signaling molecule that may lead to the changes in transcript, proteins and metabolites in order to activate some of the adaptive mechanisms [112]. Since different plant species have different sensitivity towards salinity, the imbalance in ROS level is also detected at different salt concentration, for example, 50-100 mM salinity level in Arabidopsis, tomato, wheat, rice, maize plants, $120 \mathrm{mM} \mathrm{NaCl}$ in sunflower, $255-300 \mathrm{mM}$ in ryegrass, $400 \mathrm{mM}-600 \mathrm{mM}$ in salicornia [87,115-121]. In addition to the concentration, duration of salinity is also a crucial factor in determining the alteration in cellular ROS, for example, Arabidopsis, tomato and rice show ROS imbalance after several hours of salt treatment $[87,122-128]$ while in wheat, maize, sunflower, ryegrass, salicornia the ROS level significantly increases after several days [107,121,129-132]. Additionally, higher changes in ROS under salinity is observed in older leaves as compared to younger leaves of rice and maize [133,134].

It is known that ROS level is regulated by enzyme activity of ROS producers and ROS scavengers [112]. Parallel to these ROS changes in plants during the salinity stress, there is increase of peroxidase (POD), catalase (CAT), superoxide dismutase (SOD), glucose-6phosphate dehydrogenase (G6PDH), ascorbate peroxidase (APX), glutathione S-transferases (GST), glutathione peroxidases (GPX), glutathione reductase (GR), dehydroascorbate reductase (DHAR), monodehydroascorbate reductase (MDHAR), polyphenol oxidase (PPO), phospholipid hydroperoxide glutathione peroxidase (PHGPX) in mature leaves of tomato, Arabidopsis, wheat, rice, maize, salicornia (Table 2). These ROS related enzyme activity changes are determined under similar concentration and time point of salt stress. Additionally, it was shown that NADPH oxidases are important in plant response during salinity stress [135]. Apart from enzymatic antioxidants, there is also an increase in non-enzymatic antioxidants such as AsA (Ascorbate), GSH (glutathione) and tocopherols as observed in Arabidopsis, wheat, sunflower; ryegrass, salicornia [87,89,107,121,132,136-139].

Another marker of salt stress is cell membrane injury and this can be determined by electrolyte leakage and/or higher water loss (a decrease of RWC) [140,141] (see Table 1). The cell membrane damage is generally due to the enhancement in ROS production during the salt stress [9]. Also, lipid peroxidation marker such as Malondialdehyde (MDA) content increase under salinity stress in Arabidopsis, wheat, rice, tomato, maize, ryegrass, salicornia $[37,87,116,117,129,132,142-148]$. The increase in MDA in plants experiencing salinity is detectable after the ROS molecule and enzyme activity changes. In rice and maize, it is more in older leaves than younger ones $[93,133,134]$. Additionally, the instability of the membranes may be visualized by thermography and hyperspectral reflectance techniques measurements $[11,19]$. These techniques are based on the abilities of plants to reflect and absorb light at different wavelengths (Raman, near-infrared, fluorescence etc.) depending on biophysical characteristics of the plant cell, such as disruption of electron transport chains (ETC), which changes under different stresses [149]. These changes in oxidative stress markers in plants such as ROS molecules, ROS related enzyme activity, MDA and membrane stability (leakage or RWC) are triggered not only by salt stress but other stresses as well. However, these changes are mainly detectable in early stress response of plants and in combination with morphological salt stress markers, they could be used for early predictions of salt stress in plants.

\subsection{Molecular Stress Markers}

Transcriptomic and proteomic studies reveal that stress triggers the transcript and proteome changes in plants [9]. From transcript analysis for plants under salinity stress, some of the genes change their expression under various salt concentrations. These groups 
of genes could be used as molecular markers for prediction and confirmation of salt stress in plants. In Table 2 and Figure S1 some of the genes that frequently show difference in expression during the salinity stress $(\mathrm{NaCl}$ applications) are presented.

Most of the genes used for evaluating salinity stress impact in plants are involved in cell protection, membrane transporters, osmoprotectants, ROS regulation enzymes and signal transductions (e.g., transcription factors and protein kinases) (See Table 2 and Figure S1). Also, some of these genes are associated with senescence such as NAC, NAP, WRKY 53, WRKY 25, SAG12, GDH (Table 2 and Figure S1). Measurements of genes expression from different functional groups such as ion homeostasis, biosynthesis of osmoprotectants, polyamines, synthesis of ROS scavengers and antioxidant enzymes and senescence process related genes in salt stressed-plants allow better confidence in prediction of stress impact in plants and could be used to predict the mechanism by which plants respond to salt stress. Thus, based on transcriptional changes of genes, one may predict the changes at physiological and morphological level. Additionally, the high-throughput phenotyping is identifying the genetic components of salinity tolerance [150], which could also be used as molecular markers.

Table 2. List of genes, which change their expression under salinity treatments depending on the salt concentration and time of application.

\begin{tabular}{|c|c|c|c|c|c|c|}
\hline \multirow{2}{*}{\multicolumn{2}{|c|}{ Groups/Class }} & \multirow{2}{*}{ Genes } & \multicolumn{2}{|c|}{$\begin{array}{l}\text { Inductions of Genes under Salinity } \\
\text { Conditions }\end{array}$} & \multirow{2}{*}{ Plant Species } & \multirow{2}{*}{ Reference } \\
\hline & & & $\begin{array}{c}\mathrm{NaCl} \\
\text { Concentrations }\end{array}$ & Time & & \\
\hline \multirow{3}{*}{ Stress sensors } & \multirow[t]{2}{*}{ Ca sensor kinase } & $\begin{array}{l}\text { CIPK11 } \\
\text { CIPK21 }\end{array}$ & $150 \mathrm{mM}$ & $24 \mathrm{~h}$ & A. thatiana & [151] \\
\hline & & CBL2 & $250 \mathrm{mM}$ & $24 \mathrm{~h}$ & T. aestivum & [152] \\
\hline & Protein kinase & $\begin{array}{l}\text { SOS2 } \\
\text { SOS3 }\end{array}$ & 100-200 mM & $3-6 h$ & A. thaliana & [153-155] \\
\hline \multirow{4}{*}{$\begin{array}{l}\text { Ion balance } \\
\text { regulators }\end{array}$} & Na transporters & NHX1 & $100 \mathrm{mM}-250 \mathrm{mM}$ & $3 \mathrm{~h}-21 \mathrm{~d}$ & Salicornia, T. aestivum, O. sativa & {$[38,152,156,157]$} \\
\hline & $\begin{array}{l}\text { Chloride anion } \\
\text { channel }\end{array}$ & $C L C$ & 150-200 mM & $3-9 d$ & O. sativa, A. thaliana & {$[157,158]$} \\
\hline & Cation channel & $\begin{array}{l}\text { ERD4 } \\
\text { GLRX }\end{array}$ & $200 \mathrm{mM}-300 \mathrm{mM}$ & $24 \mathrm{~h}-5 \mathrm{~d}$ & A. thatiana; T. aestivum & {$[159,160]$} \\
\hline & Transferases & GST & $150 \mathrm{mM}-255 \mathrm{mM}$ & $6-48 \mathrm{~h}$ & T. aestivum, $A$. thaliana, $R$ & {$[152,161-163]$} \\
\hline \multirow{6}{*}{ ROS regulators } & \multirow{3}{*}{ ROS scavengers } & $A P X$ & 50-255 mM & $48 \mathrm{~h}-15 \mathrm{~d}$ & $\begin{array}{l}\text { T. aestivum, O. sativa, Z. mays, } \\
\text { S.lycopersicum, Ryegrass }\end{array}$ & {$[30,45,161,164,165]$} \\
\hline & & $C A T$ & $25-255 \mathrm{mM}$ & $48 \mathrm{~h}-7 \mathrm{~d}$ & $\begin{array}{c}\text { T. aestivum, Z. mays, } S \text {. } \\
\text { lycopersicum, O. sativa, Ryegrass }\end{array}$ & {$[30,45,157,161,164,165]$} \\
\hline & & $S O D$ & $50-250 \mathrm{mM}$ & $4-75 d$ & $\begin{array}{c}\text { T. aestivum, S. lycopersicum, } \\
\text { Ryegrass }\end{array}$ & {$[30,164,165]$} \\
\hline & \multirow{3}{*}{ Redox enzymes } & $G R$ & $100-150 \mathrm{mM}$ & $24 \mathrm{~h}-7 \mathrm{~d}$ & A. thaliana, T. aestivum & {$[30,162]$} \\
\hline & & LOX & $300 \mathrm{mM}$ & $5 \mathrm{~d}$ & T. aestivum & [160] \\
\hline & & $P A O$ & $50-250 \mathrm{mM}$ & $3 \mathrm{~h}-5 \mathrm{~d}$ & T. aestivum, $A$. thaliana & {$[160,166]$} \\
\hline \multirow{3}{*}{ Cell protectors } & \multirow{2}{*}{ Proline synthesis } & $P 5 C R$ & $100 \mathrm{mM}-250 \mathrm{mM}$ & $2 \mathrm{~h}-6 \mathrm{~d}$ & $\begin{array}{l}\text { O. sativa, T. aestivum, } S \text {. } \\
\text { lycopersicum }\end{array}$ & [167-169] \\
\hline & & P5CS & $100 \mathrm{mM}-255 \mathrm{mM}$ & $2 \mathrm{~h}-6 \mathrm{~d}$ & $\begin{array}{l}\text { A. thaliana, O. sativa, S. } \\
\text { lycopersicum, Ryegrass }\end{array}$ & {$[161,167,168,170,171]$} \\
\hline & $\begin{array}{l}\text { Polyamine } \\
\text { biosynthesis }\end{array}$ & $A D C$ & $100-250 \mathrm{mM}$ & $5-7 d$ & T. aestivum, O. sativa & {$[160,172]$} \\
\hline \multirow{7}{*}{$\begin{array}{l}\text { Senescence } \\
\text { regulators }\end{array}$} & \multirow{5}{*}{$\begin{array}{l}\text { Transcriptional } \\
\text { factors }\end{array}$} & $N A C$ & $150 \mathrm{mM}-200 \mathrm{mM}$ & $12 \mathrm{~h}-24 \mathrm{~h}$ & A. thaliana, Salicornia & {$[162,173]$} \\
\hline & & NAP & $150-200 \mathrm{mM}$ & $5 \mathrm{~h}-6 \mathrm{~d}$ & A. thaliana, O. sativa & {$[174,175]$} \\
\hline & & ANAC092 & $150 \mathrm{mM}$ & $6-24 \mathrm{~h}$ & A. thaliana & {$[151,176]$} \\
\hline & & WRKY53 & $150 \mathrm{mM}$ & $4 \mathrm{~d}$ & A. thaliana & {$[177]$} \\
\hline & & WRKY25 & $150 \mathrm{mM}$ & $6 \mathrm{~h}$ & A. thaliana & [162] \\
\hline & Protease & SAG12 & $150 \mathrm{mM}$ & $4 \mathrm{~d}$ & A. thaliana & {$[176,177]$} \\
\hline & $\begin{array}{l}\text { Nitrogen } \\
\text { remobilization }\end{array}$ & GDH2 & $100-150 \mathrm{mM}$ & $48 \mathrm{~h}-6 \mathrm{~d}$ & O. sativa, A. thaliana & {$[163,178]$} \\
\hline
\end{tabular}


The molecular markers for evaluation of stresses are rarely used in research for trees and other non-model plants compared with the morphological and physiological measurements, which are less expensive and easy to conduct. However, it might be possible to generate molecular markers for less/rarely studied plants based on homologues of stress related genes that were studied well in other model or important crop plants (Table 2).

\section{Evaluation of Salinity Stress in Plants by Different Stress Markers}

Depending on the concentration and duration, generally, salinity affects all the plants, some of which, like Arabidopsis and tomato are more sensitive, whereas others such as wheat, rice, rye grass and so forth are less sensitive (See Figure 1 and Table 1). Nevertheless, the changes at molecular, physiological, morphological level under salinity stress have similar trends (either increase or decrease) for the discussed crop plants. The measurements of $\mathrm{Na}^{+}$and $\mathrm{K}^{+}$ions content in plants give strong proof for salinity stress. Other stress signs may also provide the information related to salinity strength and time of exposure. For example, the morphological stress markers such as relative weight changes and germination may predict the moderate and toxic level of salinity, respectively (Figures 1 and 2). Monitoring the morphological changes coupled with Machine learning approaches could prevent salt stress in plants in smart greenhouse. In addition, evaluating salt sensitive (Tomato or Arabidopsis) and tolerant (salicornia) plants side-by-side in a smart greenhouse could reliably predict the ability of the examined plant to tolerate the extent of salt stress. For example, if the plant being studied suffers similar to tomato or Arabidopsis while salicornia growth remains unaffected, the salinity level in the soil is likely to in the range of 100-300 mM NaCl (Figure 1 and Table 1).

The physiological traits such as chlorophyll content, RWC, electrolyte leakage, stomatal conductance, water potential, proline, glycine betaine change on application of $100 \mathrm{mM}$ $\mathrm{NaCl}$ after several days (Table 1). The molecular markers manifest the $100 \mathrm{mM}$ salt stress level prior to physiological changes. These can be detected in minutes or longer time (Tables 1 and 2). The ROS changes and ROS related enzyme changes are also early recognizable markers for stress [87,122-128]. Generally, the ROS level changes have wave shape changes during the time of stress exposure, this fluctuation of ROS occurs in stressed and also in normal conditions $[179,180]$. Thus, to define the fluctuation in ROS level under moderate stress, it is better to measure ROS level in time-series rather than image-type measurements, which is a snapshot measurement only for one time point [181]. Spectrometric or staining methods are commonly used for ROS detection under salinity stress [182] but also the imaging system are rapidly developing for monitoring redox state of the plant cell [183-185] allowing measurement of ROS changes in vivo [186].

Basically, these molecular, physiological and morphological changes in plants follow the order, where the first changes by stress will be visualized by molecular, followed by biochemical then physiological and at last by morphological markers (Figure 3, Tables 1 and 2). Additionally, the ROS molecule plays an important role in signaling for stress and thus, these oxidative stress markers changes are detectable at similar time with molecular markers changes after exposure by salt application (see time points in References [87,122-128] and Table 2). Therefore, each stress marker has order in terms of time observation after stress, where the oxidative and molecular stress markers are early sensors for stress compared with other markers but they will not specify stress type.

Additionally, if the measurements will focus on specific locations in plant organs like young and/or older leaves then the recognition of stress in plants will be detectable in early stages. For example, the old leaves are accumulating salt earlier than young leaves in crop plants (Table 3). Moreover, the visible symptoms of senescence such as decrease in total chlorophyll and/or chlorophyll a, b content and decrease of photosynthesis efficiency was also higher in old leaves in comparison to young leaves of crop plants upon $\mathrm{NaCl}$ application (Table 3). Chlorophyll content measurements, fluorescence were also greater decreased in old leaves under salt stress $[93,187]$ and this measurement does not require the detachment of the leaves (Table 3). Additionally, the degradation of total soluble proteins 
was higher in old leaves as compared to young leaves under salinity stress (Table 3). Also, it was shown that the ROS levels and catalase activity were higher in old leaves than young leaves after salt stress applications (Table 3). Other signs of senescence such as ethylene gas production was observed after salt treatments [90]. Also, the remobilization of nitrogen and the formation of the autophagosome under salinity stress may also be used as markers for the salinity stress in plants [188]. Generally, the senescence symptoms in leaves could be detected in earlier stages by using molecular markers (Table 2 and Figure 3). Thus, some morphological, physiological and molecular changes under salt stress are highly detectable in older (mature) leaves compared to other organs or whole plant and measurements of these stress markers on a specific area of plants would increase efficiency of deep learning approaches on phenotyping the salt stressed plants.

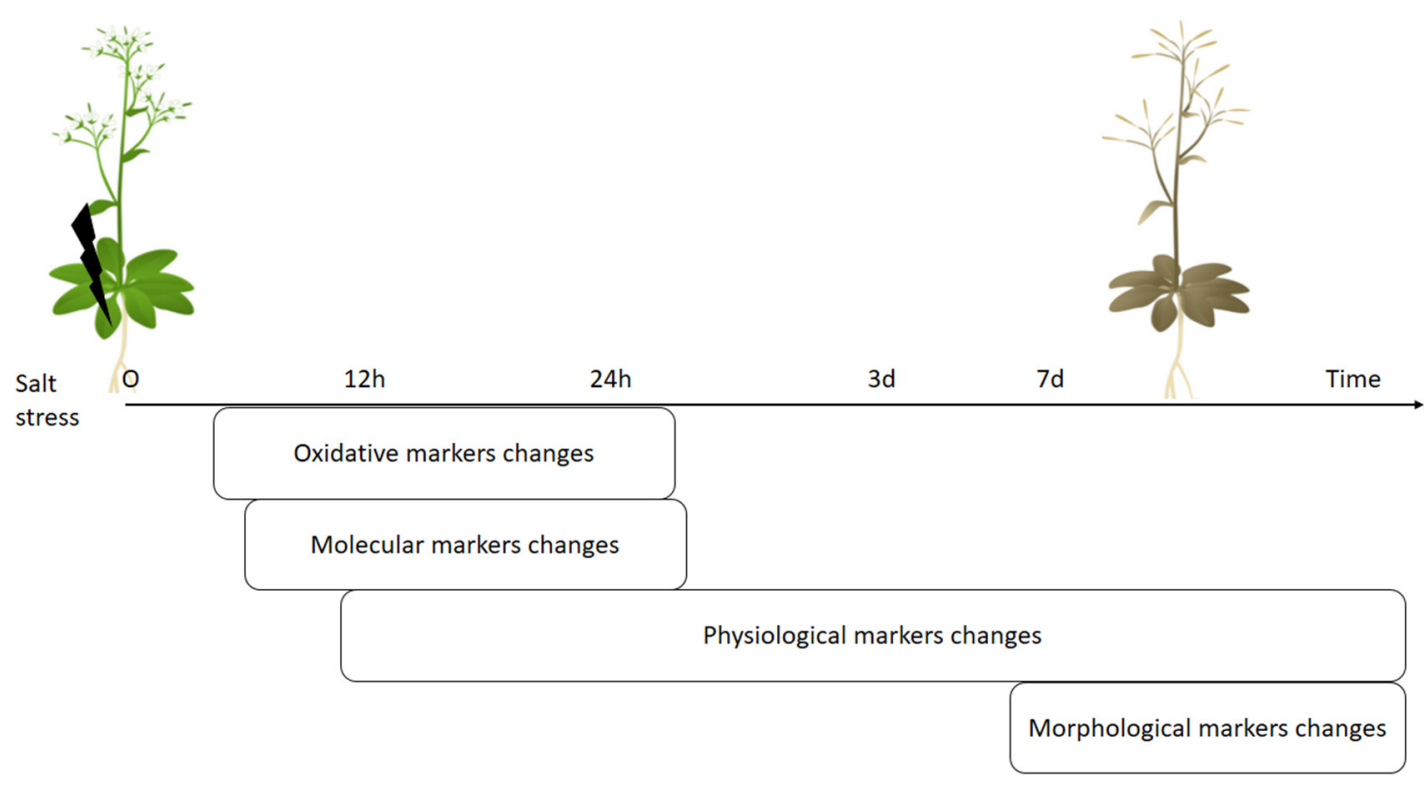

Figure 3. Scheme of sequence of changes at different levels in plants triggered by salt stress.

Table 3. Differences in old and young leaves of crop plants triggered by salinity stress.

\begin{tabular}{|c|c|c|}
\hline Parameters & Plants & References \\
\hline $\begin{array}{l}\text { Higher accumulation of } \mathrm{Na}^{+} \text {in old leaves than } \\
\text { young leaves }\end{array}$ & Wheat, Barley, Rice, Maize, Sunflower & {$[93,133,134,187,189-193]$} \\
\hline $\begin{array}{l}\text { Higher accumulation of } \mathrm{Cl}^{-} \text {in old leaves than } \\
\text { young leaves }\end{array}$ & Wheat and Barley, Sunflower & {$[187,189,191]$} \\
\hline $\begin{array}{l}\text { Higher photochemical efficiency decrease in old } \\
\text { leaves than young leaves }\end{array}$ & Wheat and Barley, Rice & {$[93,187]$} \\
\hline $\begin{array}{l}\text { Higher decrease of total chlorophyll content in old } \\
\text { leaves than young leaves }\end{array}$ & Wheat, Barley, Sunflower & {$[93,192,194]$} \\
\hline $\begin{array}{l}\text { Higher soluble protein decrease in old leavesthan } \\
\text { young leaves }\end{array}$ & Rice, Wheat & {$[93,195]$} \\
\hline $\begin{array}{l}\text { Higher increase in MDA content in old leaves than } \\
\text { young leaves than young leaves }\end{array}$ & Rice, Maize & {$[93,133,134]$} \\
\hline $\begin{array}{l}\text { Higher electrolyte leakage in older leaves than } \\
\text { young leaves }\end{array}$ & Rice, Maize & {$[93,134]$} \\
\hline $\begin{array}{l}\text { Higher ROS reduction and } \mathrm{H}_{2} \mathrm{O}_{2} \text { generation in } \\
\text { older leaves than young leaves }\end{array}$ & Rice, Maize & {$[133,134]$} \\
\hline $\begin{array}{l}\text { Higher increase in catalase activity in older leaves } \\
\text { compare to young }\end{array}$ & Rice, Maize & {$[133,134]$} \\
\hline
\end{tabular}




\section{Prediction and Identification of Stressed Plants Using Deep Learning Approaches}

Machine learning techniques are developing rapidly for agricultural needs such as for plant recognition, plant or fruits counting, classification of crop types, phenotyping of various plant species, classification of mutants, leaf counting, identification of vein patterns and leaf characteristics detection of plant diseases, weed control, as well as the prediction of biotic stresses in plant leaves [17]. Basically, these approaches analyze big data of images, from monitoring various morphological changes in plants to identifying and/or classifying and/or phenotyping plants $[17,196]$. There are so many different machine learning approaches out there but some are frequently applied in plants, such as Artificial Neural Networks (ANN), Logistic Regression, Random Forest, Support Vector Machines (SVM), K-Nearest Neighbors (KNN) and Deep Learning are commonly used in prediction and/or classification and/or detection of stress in plants [17,197,198]. Among these different machine learning approaches, the deep learning models such as Convolutional Neural Networks (CNN), Recurrent Neural Networks (RNN), Long Short-Term Memory (LSTM) are recently on the increase for use in imaging analysis. This is because the CNN has shown great accuracy in finding specific patterns in image data, so it is mainly used for identification and classification of different damages in plant leaves, especially for searching the damages caused by biotic and abiotic stimuli [17]. The other models, RNN and LSTM, are also valuable in the analysis of time series image data [17], which is important for prediction of damages in plant leaves. It has also been pointed out that various combinations of deep learning approaches can be used for classification and prediction of plant characteristics $[17,199]$ and these combinations of different models can be used in the future for accurate diagnosis of signs of stress in plants for smart greenhouse procedures.

Generally, all these high-throughput phenotyping technologies are based on the analysis of different type of images such as RGB imaging, near-infrared imaging, infrared thermal imaging and fluorescence imaging [200-202]. These prediction of plant diseases and pest attacks or environmental impact on plants by machine learning approaches are mostly focused on identification of visual symptoms of biotic damage [17], which are discussed as morphological stress markers. As mentioned above, these morphological signs appear in plants later than physiological, oxidative and molecular stress markers (Figure 3). Currently, deep learning approaches are beginning to combine morphological stress markers data (visible signs in leaves) with physiological stress markers such as transpiration rate, biomass, water content, biochemical components (sodium concentration), photosynthetic efficiency, caratenoides [19,203-205]. However, to the best of our knowledge, there is still no extensive research on deep learning approaches for predicting abiotic or biotic stress in plants that use a combination of oxidative, molecular and morphological markers. In addition, using deep learning analysis for attached or detached leaves and whether these leaves are mature or young for better prediction has not been done yet. As previously mentioned, physiological and morphological stress marker analysis of older leaves (lower leaves) shows greater changes under salinity stress rather than young leaves (Table 2) but it has not yet been shown how this could affect prediction or identification damage using deep learning approaches. In addition, deep learning approaches for predicting salinity stress in plants have only been applied for a single plant species (Barley or Spinach or Okra) [19-22]. It would be interesting if machine learning approaches were applied in different plant species, specifically to the salt sensitive (Tomato or Arabidopsis) and tolerant (salicornia) plants, for their identification and prediction of salinity stress in plant (Figure 1 and Table 1). Additionally, it successfully generated different transgenic plants with different gene modifications, for example, it generated fused constructions of the gene promoter region with GFP proteins [206]. These transgenic plants (in Table 2) with GFP protein, could be useful for evaluation of molecular stress markers and prediction of salinity stress in plants. Thus, we believe that the following suggestions have potential for application through deep learning approaches for stress prediction in plants: (a) analysis of images data with other stress markers such as oxidative and/or molecular markers, (b) emphasis on analysis of mature leaves versus young leaves, (c) use of control plant data 
such as stress-sensitive or stress-tolerant plants or the transgenic plant promoter fused with GFP and other fluorescent markers.

\section{Conclusions}

Continuous expansion of soil salinization area is inversely proportional to crop yield and this poses a challenge to global food security. To improve plant adaptability and performance to such condition, different areas such as plant stress physiology, molecular biology, genetic engineering, biotechnology are being exploited. Machine learning approaches are promising in developing smart greenhouse, by phenotyping plants and controlling the environmental growth parameters. Developing such controlled growth room conditions require not only equipped imaging technologies but also important physiological, oxidative and molecular data. Morphological markers in plants such as root or shoot growth, germination, flowering time indicate obvious signs of stress but also the appearance of senescence symptoms under salinity stress is an important sign-which appear early in older leaves after salt application. From physiological parameters, the chlorophyll content, RWC, electrolyte leakage, stomatal conductance, water potential, proline, glycine betaine changes in plants are commonly detected under $\mathrm{NaCl}$ stress. These physiological changes manifest themselves before the molecular markers. ROS and ROS-related-enzyme changes are also early recognizable markers for stress. Molecular and oxidative stress maybe useful in early detection of salinity stress impact. Still, each stress marker, either morphological, physiological, oxidative or molecular changes in plants, have their own limitation. An integrated approach and usage of different sensors for specific areas of the plant such as old leaves would increase the sensitivity in detection of salinity stress in plants. However, this integration of morphological, physiological, molecular and deep learning parameters requires concerted studies.

Supplementary Materials: The following are available online at https:/ / www.mdpi.com/2223-7 747/10/2/243/s1, Figure S1: Change in expression of genes in Arabidopsis, wheat, rice and maize triggered by salt stresses.

Author Contributions: Conceptualization, A.S.; investigation, A.O. and A.S.; data curation, A.O. and A.S.; writing-original draft preparation, A.O.; writing-review and editing, J.O.O. and S.S.; visualization, A.S. and S.S.; supervision, A.S.; project administration, A.S.; funding acquisition, A.S. All authors have read and agreed to the published version of the manuscript.

Funding: This research was funded by Faculty Development Competitive Research Grant Program (FDCRG 2020) at Nazarbayev University, Kazakhstan. Grant ID number 240919FD3939.

Institutional Review Board Statement: Not applicable.

Informed Consent Statement: Not applicable.

Data Availability Statement: Data is contained within the article or supplementary material.

Acknowledgments: The authors would like to thank Adnan Yazici for support and consultations. We would like to thank Damira Kanayeva for help and support.

Conflicts of Interest: The authors declare no conflict of interest. The funders had no role in the design of the study; in the collection, analyses or interpretation of data; in the writing of the manuscript or in the decision to publish the results.

\section{References}

1. Flowers, T.J.; Yeo, A.R. Effects of salinity on plant growth and crops yields. In Environmental Stress in Plants; Cherry, J.H., Ed.; NATO ASI Series; Springer: Berlin, Germany, 1989; Volume G19, pp. 101-119.

2. Ali, Y.; Aslam, Z.; Ashraf, M.Y.; Tahir, G.R. Effect of salinity on chlorophyll concentration, leaf area, yield and yield components of rice genotypes grown under saline environment. Int. J. Environ. Sci. Technol. 2004. [CrossRef]

3. Yermiyahu, U.; Ben-Gal, A.; Keren, R.; Reid, R.J. Combined effect of salinity and excess boron on plant growth and yield. Plant Soil 2008. [CrossRef]

4. Ivushkin, K.; Bartholomeus, H.; Bregt, A.K.; Pulatov, A.; Kempen, B.; de Sousa, L. Global mapping of soil salinity change. Remote Sens. Environ. 2019. [CrossRef] 
5. Khatoon, A.; Qureshi, M.S.; Hussain, M.K. Effect of Salinity on Some Yield Parameters of Sunflower (Helianthus annuus L.). Int. J. Agric. Biol. 2000, 2, 382-384.

6. Abd El-Kader, A.A.; Mohamedin, A.A.M.; Ahmed, M.K.A. Growth and Yield of Sunflower as Affected by Different Salt Affected Soils. Int. J. Agric. Biol. 2006, 8, 583-587.

7. Chamekh, Z.; Ayadi, S.; Karmous, C.; Trifa, Y.; Amara, H.; Boudabbous, K.; Yousfi, S.; Serret, M.D.; Araus, J.L. Comparative effect of salinity on growth, grain yield, water use efficiency, $\delta 13 \mathrm{C}$ and $\delta 15 \mathrm{~N}$ of landraces and improved durum wheat varieties. Plant Sci. 2016. [CrossRef]

8. Elkhatib, H.A.; Elkhatib, E.A.; Khalaf Allah, A.M.; El-Sharkawy, A.M. Yield Response of Salt-Stressed Potato to Potassium Fertilization: A Preliminary Mathematical Model. J. Plant Nutr. 2004. [CrossRef]

9. Gupta, B.; Huang, B. Mechanism of salinity tolerance in plants: Physiological, biochemical, and molecular characterization. Int. J. Genomics 2014. [CrossRef]

10. Ondrasek, G.; Rengel, Z.; Veres, S. Soil Salinisation and Salt Stress in Crop Production. In Abiotic Stress in Plants—Mechanisms and Adaptations; Shanker, A.K., Venkateswarlu, B., Eds.; InTech: Rijeka, Croatia, 2011; pp. 171-190. ISBN 978-953-307-394-1. [CrossRef]

11. Sytar, O.; Brestic, M.; Zivcak, M.; Olsovska, K.; Kovar, M.; Shao, H.; He, X. Applying hyperspectral imaging to explore natural plant diversity towards improving salt stress tolerance. Sci. Total Environ. 2017. [CrossRef]

12. Munns, R.; Tester, M. Mechanisms of salinity tolerance. Annu. Rev. Plant Biol. 2008, 59, 651-681. [CrossRef]

13. Mbarki, S.; Sytar, O.; Cerda, A.; Zivcak, M.; Rastogi, A.; He, X.; Zoghlami, A.; Abdelly, C.; Brestic, M. Strategies to mitigate the salt stress effects on photosynthetic apparatus and productivity of crop plants. In Salinity Responses and Tolerance in Plants, Volume 1: Targeting Sensory, Transport and Signaling Mechanisms; Springer International Publishing: Cham, Switzerland, 2018; pp. 85-136. ISBN 9783319756714.

14. Samuel, A.L. Some Studies in Machine Learning. IBM J. Res. Dev. 1959, 3, 210-229. [CrossRef]

15. Lecun, Y.; Bengio, Y.; Hinton, G. Deep learning. Nature 2015, 521, 436-444. [CrossRef]

16. Zhang, L.; Tan, J.; Han, D.; Zhu, H. From machine learning to deep learning: Progress in machine intelligence for rational drug discovery. Drug Discov. Today 2017, 22, 1680-1685. [CrossRef]

17. Kamilaris, A.; Prenafeta-Boldú, F.X. Deep learning in agriculture: A survey. Comput. Electron. Agric. 2018, 147, 70-90. [CrossRef]

18. Liakos, K.G.; Busato, P.; Moshou, D.; Pearson, S.; Bochtis, D. Machine learning in agriculture: A review. Sensors (Switzerland) 2018, 18, 2674. [CrossRef] [PubMed]

19. Feng, X.; Zhan, Y.; Wang, Q.; Yang, X.; Yu, C.; Wang, H.; Tang, Z.Y.; Jiang, D.; Peng, C.; He, Y. Hyperspectral imaging combined with machine learning as a tool to obtain high-throughput plant salt-stress phenotyping. Plant J. 2020. [CrossRef] [PubMed]

20. Behmann, J.; Steinrücken, J.; Plümer, L. Detection of early plant stress responses in hyperspectral images. ISPRS J. Photogramm. Remote Sens. 2014. [CrossRef]

21. Chen, D.; Neumann, K.; Friedel, S.; Kilian, B.; Chen, M.; Altmann, T.; Klukas, C. Dissecting the phenotypic components of crop plant growthand drought responses based on high-throughput image analysis w open. Plant Cell 2014. [CrossRef]

22. Kersting, K.; Xu, Z.; Wahabzada, M.; Bauckhage, C.; Thurau, C.; Roemer, C.; Ballvora, A.; Rascher, U.; Leon, J.; Pluemer, L. Presymptomatic prediction of plant drought stress using Dirichlet-aggregation regression on hyperspectral images. In Proceedings of the Twenty-Sixth AAAI Conference on Artificial Intelligence, Toronto, ON, Canada, 22-26 July 2012; AAAI Publications: Toronto, ON, Canada, 2012; pp. 302-308.

23. Gong, H.J.; Randall, D.P.; Flowers, T.J. Silicon deposition in the root reduces sodium uptake in rice (Oryza sativa L.) seedlings by reducing bypass flow. Plant Cell Environ. 2006. [CrossRef]

24. Turan, M.A.; Elkarim, A.H.A.; Taban, N.; Taban, S. Effect of salt stress on growth, stomatal resistance, proline and chlorophyll concentrations on maize plant. Afr. J. Agric. Res. 2009, 4, 893-897.

25. Li, N.; Wang, X.; Ma, B.; Du, C.; Zheng, L.; Wang, Y. Expression of a Na ${ }^{+} / \mathrm{H}^{+}$antiporter RtNHX1 from a recretohalophyte Reaumuria trigyna improved salt tolerance of transgenic Arabidopsis thaliana. J. Plant Physiol. 2017. [CrossRef] [PubMed]

26. Pérez-Tornero, O.; Tallón, C.I.; Porras, I.; Navarro, J.M. Physiological and growth changes in micropropagated Citrus macrophylla explants due to salinity. J. Plant Physiol. 2009. [CrossRef] [PubMed]

27. Ghaleb, W.S.; Sawwan, J.S.; Akash, M.W.; Al-Abdallat, A.M. In vitro response of two citrus rootstocks to salt stress. Int. J. Fruit Sci. 2010. [CrossRef]

28. Abbas, G.; Saqib, M.; Akhtar, J.; Basra, S.M.A. Salinity tolerance potential of two acacia species at early seedling stage. Pak. J. Agric. Sci. 2013, 50, 683-688.

29. Al-Abdoulhadi, I.A.; Dinar, H.A.; Ebert, G.; Büttner, C. Effect of salinity on leaf growth, leaf injury and biomass production in date palm (Phoenix dactylifera L.) cultivars. Indian J. Sci. Technol. 2011. [CrossRef]

30. Hemida, K.A.; Ali, R.M.; Ibrahim, W.M.; Sayed, M.A. Ameliorative role of some antioxidant compounds on physiological parameters and antioxidants response of wheat (Triticum aestivum L.) seedlings under salinity stress. Life Sci. J. 2014, 11, 324-342.

31. Umnajkitikorn, K.; Faiyue, B. Enhancing Antioxidant Properties of Germinated Thai rice (Oryza sativa L.) cv. Kum Doi Saket with Salinity. Rice Res. Open Access 2013. [CrossRef]

32. Ghars, M.A.; Parre, E.; Debez, A.; Bordenave, M.; Richard, L.; Leport, L.; Bouchereau, A.; Savouré, A.; Abdelly, C. Comparative salt tolerance analysis between Arabidopsis thaliana and Thellungiella halophila, with special emphasis on $\mathrm{K}^{+} / \mathrm{Na}^{+}$selectivity and proline accumulation. J. Plant Physiol. 2008. [CrossRef] 
33. Sultana, N.; Ikeda, T.; Itoh, R. Effect of $\mathrm{NaCl}$ salinity on photosynthesis and dry matter accumulation in developing rice grains. Environ. Exp. Bot. 1999. [CrossRef]

34. Gautam, S.; Singh, P.K. Salicylic acid-induced salinity tolerance in corn grown under NaCl stress. Acta Physiol. Plant. 2009. [CrossRef]

35. Shiyab, S.M.; Shatnawi, M.A.; Shibli, R.A.; Al Smeirat, N.G.; Ayad, J.; Akash, M.W. Growth, nutrient acquisition, and physiological responses of hydroponic grown tomato to sodium chloride salt induced stress. J. Plant Nutr. 2013. [CrossRef]

36. Wang, Z.Q.; Yuan, Y.Z.; Ou, J.Q.; Lin, Q.H.; Zhang, C.F. Glutamine synthetase and glutamate dehydrogenase contribute differentially to proline accumulation in leaves of wheat (Triticum aestivum) seedlings exposed to different salinity. J. Plant Physiol. 2007. [CrossRef] [PubMed]

37. Aghaleh, M.; Niknam, V.; Ebrahimzadeh, H.; Razavi, K. Salt stress effects on growth, pigments, proteins and lipid peroxidation in Salicornia persica and S. europaea. Biol. Plant. 2009. [CrossRef]

38. Lv, S.; Jiang, P.; Chen, X.; Fan, P.; Wang, X.; Li, Y. Multiple compartmentalization of sodium conferred salt tolerance in Salicornia europaea. Plant Physiol. Biochem. 2012. [CrossRef] [PubMed]

39. Gul, B.; Ansari, R.; Khan, M.A. Salt tolerance of Salicornia Utahensis from the great basin desert. Pak. J. Bot. 2009, 41, 2925-2932.

40. Ventura, Y.; Sagi, M. Halophyte crop cultivation: The case for salicornia and sarcocornia. Environ. Exp. Bot. 2013. [CrossRef]

41. Singh, A.; Jha, S.K.; Bagri, J.; Pandey, G.K. ABA inducible rice protein phosphatase 2C confers ABA insensitivity and abiotic stress tolerance in Arabidopsis. PLoS ONE 2015. [CrossRef]

42. Renault, H.; Roussel, V.; El Amrani, A.; Arzel, M.; Renault, D.; Bouchereau, A.; Deleu, C. The Arabidopsis pop2-1 mutant reveals the involvement of GABA transaminase in salt stress tolerance. BMC Plant Biol. 2010. [CrossRef]

43. Singh, R.P.; Jha, P.N. A halotolerant bacterium Bacillus licheniformis HSW-16 augments induced systemic tolerance to salt stress in wheat plant (Triticum aestivum). Front. Plant Sci. 2016. [CrossRef]

44. El-Hendawy, S.E.; Hu, Y.; Yakout, G.M.; Awad, A.M.; Hafiz, S.E.; Schmidhalter, U. Evaluating salt tolerance of wheat genotypes using multiple parameters. Eur. J. Agron. 2005. [CrossRef]

45. Azooz, M.M.; Ismail, A.M.; Elhamd, M.F.A. Growth, lipid peroxidation and antioxidant enzyme activities as a selection criterion for the salt tolerance of maize cultivars grown under salinity stress. Int. J. Agric. Biol. 2009, 11, 21-26.

46. Sultana, R.; Uddin, M.N.; Rahim, M.A.; Fakir, M.S.A. Effect of salt stress on germination and seedling growth in four maize genotypes. Pak. J. Biol. Sci. 2016, 4, 359-360. [CrossRef]

47. Saboora, A.; Kiarostami, K.; Behroozbayati, F.; Hajihashemi, S. Salinity ( $\mathrm{NaCl}$ ) tolerance of wheat genotypes at germination and early seedling growth. Pak. J. Biol. Sci. 2006. [CrossRef]

48. Al-aghabary, K.; Zhu, Z.; Shi, Q. Influence of silicon supply on chlorophyll content, chlorophyll fluorescence, and antioxidative enzyme activities in tomato plants under salt stress. J. Plant Nutr. 2004. [CrossRef]

49. Debouba, M.; Maâroufi-Dghimi, H.; Suzuki, A.; Ghorbel, M.H.; Gouia, H. Changes in growth and activity of enzymes involved in nitrate reduction and ammonium assimilation in tomato seedlings in response to $\mathrm{NaCl}$ stress. Ann. Bot. 2007. [CrossRef]

50. Delgado, I.C.; Sánchez-Raya, A.J. Effects of sodium chloride and mineral nutrients on initial stages of development of sunflower life. Commun. Soil Sci. Plant Anal. 2007. [CrossRef]

51. Burgos, P.A.; Roldan, M.; Donaire, J.P.; Agui, I. Effect of sodium chloride on growth, ion content, and hydrogen ion extrusion activity of sunflower and jojoba roots. J. Plant Nutr. 1993. [CrossRef]

52. Shahbaz, M.; Ashraf, M.; Akram, N.A.; Hanif, A.; Hameed, S.; Joham, S.; Rehman, R. Salt-induced modulation in growth, photosynthetic capacity, proline content and ion accumulation in sunflower (Helianthus annuus L.). Acta Physiol. Plant. 2011. [CrossRef]

53. Tang, J.; Camberato, J.J.; Yu, X.; Luo, N.; Bian, S.; Jiang, Y. Growth response, carbohydrate and ion accumulation of diverse perennial ryegrass accessions to increasing salinity. Sci. Hortic. (Amst.) 2013. [CrossRef]

54. Chu, T.N.; Tran, B.T.H.; Van Bui, L.; Hoang, M.T.T. Plant growth-promoting rhizobacterium Pseudomonas PS01 induces salt tolerance in Arabidopsis thaliana. BMC Res. Notes 2019. [CrossRef]

55. Butt, H.I.; Yang, Z.; Gong, Q.; Chen, E.; Wang, X.; Zhao, G.; Ge, X.; Zhang, X.; Li, F. GaMYB85, an R2R3 MYB gene, in transgenic Arabidopsis plays an important role in drought tolerance. BMC Plant Biol. 2017. [CrossRef] [PubMed]

56. Galpaz, N.; Reymond, M. Natural variation in Arabidopsis thaliana revealed a genetic network controlling germination under salt stress. PLoS ONE 2010. [CrossRef] [PubMed]

57. Xu, Z.; Raza, Q.; Xu, L.; He, X.; Huang, Y.; Yi, J.; Zhang, D.; Shao, H.B.; Ma, H.; Ali, Z. GmWRKY49, a salt-responsive nuclear protein, improved root length and governed better salinity tolerance in transgenic Arabidopsis. Front. Plant Sci. 2018. [CrossRef] [PubMed]

58. Ferdosizadeh, L.; Ahmad Sadat-Noori, S.; Zare, N.; Saghafi, S. Assessment of Diode Laser Pretreatments on Germination and Yield of Wheat (Triticum aestivum L.) under Salinity Stress. World J. Agric. Res. 2013. [CrossRef]

59. Begum, F.; Karmoker, J.L.; Fattah, Q.A.; Maniruzzaman, A.F.M. The effect of salinity on germination and its correlation with $\mathrm{K}^{+}$, $\mathrm{Na}^{+}, \mathrm{Cl}^{-}$accumulation in germinating seeds of Triticum aestivum L. cv. akbar. Plant Cell Physiol. 1992, 33, $1009-1014$.

60. Djanaguiraman, M.; Senthil, A.; Ramadass, R. Assessment of rice genotypes for salinity tolerance at germination and seedling stage. Assessment 2003, 90, 506-510.

61. Aliu, S.; Rusinovci, I.; Fetahu, S.; Gashi, B.; Simeonovska, E.; Rozman, L. The effect of salt stress on the germination of maize (Zea mays L.) seeds and photosynthetic pigments. Acta Agric. Slov. 2015. [CrossRef] 
62. Mohammad, M.; Jun, Z.; Guoying, W. Impact of salinity stress on seed germination indices of maize (Zea mays L.) genotypes. Kragujev. J. Sci. 2014. [CrossRef]

63. Fellner, M.; Sawhney, V.K. Seed germination in a tomato male-sterile mutant is resistant to osmotic, salt and low-temperature stresses. Theor. Appl. Genet. 2001. [CrossRef]

64. Torres-Schumann, S.; Godoy, J.A.; Pintor-Toro, J.A.; Moreno, F.J.; Rodrigo, R.M.; Garcia-Herdugo, G. NaCl Effects on Tomato Seed Germination, Cell Activity and Ion Allocation. J. Plant Physiol. 1989. [CrossRef]

65. Bozcuk, S. Effects of kinetin and salinity on germination of tomato, barley and cotton seeds. Ann. Bot. 1981. [CrossRef]

66. El Midaoui, M.; Benbella, M.; Talouizete, A. Effect of sodium chloride on sunflower (helianthus annuus 1.) seed germination. Helia 2002. [CrossRef]

67. Khan, M.A.; Gul, B. Halophyte seed germination. In Ecophysiology of High Salinity Tolerant Plants; Khan, M.A., Weber, D.J., Eds.; Springer Academic Publishers: Dordrecht, The Netherlands, 2006; pp. 11-31. [CrossRef]

68. Zörb, C.; Schmitt, S.; Neeb, A.; Karl, S.; Linder, M.; Schubert, S. The biochemical reaction of maize (Zea mays L.) to salt stress is characterized by a mitigation of symptoms and not by a specific adaptation. Plant Sci. 2004. [CrossRef]

69. Julkowska, M.M.; Koevoets, I.T.; Mol, S.; Hoefsloot, H.; Feron, R.; Tester, M.A.; Keurentjes, J.J.B.; Korte, A.; Haring, M.A.; De Boer, G.J.; et al. Genetic components of root architecture remodeling in response to salt stress. Plant Cell 2017. [CrossRef] [PubMed]

70. Ryu, J.Y.; Lee, H.J.; Seo, P.J.; Jung, J.H.; Ahn, J.H.; Park, C.M. The Arabidopsis floral repressor BFT delays flowering by competing with FT for FD binding under high salinity. Mol. Plant 2014. [CrossRef]

71. Ryu, J.Y.; Park, C.M.; Seo, P.J. The floral repressor BROTHER OF FT AND TFL1 (BFT) modulates flowering initiation under High salinity in Arabidopsis. Mol. Cells 2011. [CrossRef]

72. Park, H.J.; Kim, W.Y.; Yun, D.J. A role for GIGANTEA: Keeping the balance between flowering and salinity stress tolerance. Plant Signal. Behav. 2013. [CrossRef]

73. Lutts, S.; Kinet, J.M.; Bouharmont, J. Changes in plant response to $\mathrm{NaCl}$ during development of rice (Oryza sativa L.) varieties differing in salinity resistance. J. Exp. Bot. 1995. [CrossRef]

74. Khatun, S.; Rizzo, C.A.; Flowers, T.J. Genotypic variation in the effect of salinity on fertility in rice. Plant Soil 1995. [CrossRef]

75. Khorasani, S.; Mostafavi, K.; Heidarian, A. Response of Maize (Zea mays L.) hybrids and inbred lines to salinity stress under field condition. Tech. J. Eng. Appl. Sci. 2011, 2, 1-7.

76. Castillo, E.G.; Tuong, T.P.; Ismail, A.M.; Inubushi, K. Response to salinity in rice: Comparative effects of osmotic and ionic stresses. Plant Prod. Sci. 2007. [CrossRef]

77. Romdhane, L.; Dal Cortivo, C.; Vamerali, T.; Radhouane, L. Effects of drought and salinity on maize phenology, morphology and productivity in a semi-arid environment. Ital. J. Agrometeorol. 2016. [CrossRef]

78. Lefèvre, I.; Gratia, E.; Lutts, S. Discrimination between the ionic and osmotic components of salt stress in relation to free polyamine level in rice (Oryza sativa). Plant Sci. 2001. [CrossRef]

79. Jedmowski, C.; Ashoub, A.; Brüggemann, W. Reactions of Egyptian landraces of Hordeum vulgare and Sorghum bicolor to drought stress, evaluated by the OJIP fluorescence transient analysis. Acta Physiol. Plant. 2013. [CrossRef]

80. Turan, M.A.; Katkat, V.; Taban, S. Variations in proline, chlorophyll and mineral elements contents of wheat plants grown under salinity stress. J. Agron. 2007. [CrossRef]

81. Datta, J.; Nag, S.; Banerjee, A.; Mondai, N. Impact of salt stress on five varieties of Wheat (Triticum aestivum L.) cultivars under laboratory condition. J. Appl. Sci. Environ. Manag. 2010. [CrossRef]

82. Vaidyanathan, H.; Sivakumar, P.; Chakrabarty, R.; Thomas, G. Scavenging of reactive oxygen species in NaCl-stressed rice (Oryza sativa L.)—Differential response in salt-tolerant and sensitive varieties. Plant Sci. 2003. [CrossRef]

83. Shibli, R.A.; Kushad, M.; Yousef, G.G.; Lila, M.A. Physiological and biochemical responses of tomato microshoots to induced salinity stress with associated ethylene accumulation. Plant Growth Regul. 2007. [CrossRef]

84. Choi, J.Y.; Seo, Y.S.; Kim, S.J.; Kim, W.T.; Shin, J.S. Constitutive expression of CaXTH3, a hot pepper xyloglucan endotransglucosylase/hydrolase, enhanced tolerance to salt and drought stresses without phenotypic defects in tomato plants (Solanum lycopersicum cv. Dotaerang). Plant Cell Rep. 2011. [CrossRef]

85. Poór, P.; Gémes, K.; Horváth, F.; Szepesi, Á.; Simon, M.L.; Tari, I. Salicylic acid treatment via the rooting medium interferes with stomatal response, $\mathrm{CO}_{2}$ fixation rate and carbohydrate metabolism in tomato, and decreases harmful effects of subsequent salt stress. Plant Biol. 2011. [CrossRef]

86. Navarro, J.M.; Martínez, V.; Carvajal, M. Ammonium, bicarbonate and calcium effects on tomato plants grown under saline conditions. Plant Sci. 2000. [CrossRef]

87. Ellouzi, H.; Ben Hamed, K.; Cela, J.; Munné-Bosch, S.; Abdelly, C. Early effects of salt stress on the physiological and oxidative status of Cakile maritima (halophyte) and Arabidopsis thaliana (glycophyte). Physiol. Plant. 2011. [CrossRef] [PubMed]

88. M'rah, S.; Ouerghi, Z.; Eymery, F.; Rey, P.; Hajji, M.; Grignon, C.; Lachaâl, M. Efficiency of biochemical protection against toxic effects of accumulated salt differentiates Thellungiella halophila from Arabidopsis thaliana. J. Plant Physiol. 2007. [CrossRef] [PubMed]

89. Hao, L.; Zhao, Y.; Jin, D.; Zhang, L.; Bi, X.; Chen, H.; Xu, Q.; Ma, C.; Li, G. Salicylic acid-altering Arabidopsis mutants response to salt stress. Plant Soil 2012. [CrossRef]

90. Wang, H.; Liang, X.; Wan, Q.; Wang, X.; Bi, Y. Ethylene and nitric oxide are involved in maintaining ion homeostasis in Arabidopsis callus under salt stress. Planta 2009. [CrossRef] 
91. Shi, H.; Lee, B.H.; Wu, S.J.; Zhu, J.K. Overexpression of a plasma membrane $\mathrm{Na}^{+} / \mathrm{H}^{+}$antiporter gene improves salt tolerance in Arabidopsis thaliana. Nat. Biotechnol. 2003. [CrossRef]

92. Huang, X.Y.; Chao, D.Y.; Gao, J.P.; Zhu, M.Z.; Shi, M.; Lin, H.X. A previously unknown zinc finger protein, DST, regulates drought and salt tolerance in rice via stomatal aperture control. Genes Dev. 2009. [CrossRef]

93. Lutts, S.; Kinet, J.M.; Bouharmont, J. NaCl-induced senescence in leaves of rice (Oryza sativa L.) cultivars differing in salinity resistance. Ann. Bot. 1996. [CrossRef]

94. Yoon, B.S.; Jin, C.; Un, P.S.; Cho, D.H. Change in Photosynthesis, Proline Content, and Osmotic Potential of Corn Seedling under High-Saline Condition. Korean J. Crop Sci. 2005, 50, 28-31.

95. Yang, X.; Lu, C. Photosynthesis is improved by exogenous glycinebetaine in salt-stressed maize plants. Physiol. Plant. 2005. [CrossRef]

96. Estrada, B.; Aroca, R.; Barea, J.M.; Ruiz-Lozano, J.M. Native arbuscular mycorrhizal fungi isolated from a saline habitat improved maize antioxidant systems and plant tolerance to salinity. Plant Sci. 2013. [CrossRef] [PubMed]

97. Katerji, N.; van Hoorn, J.W.; Hamdy, A.; Karam, F.; Mastrorilli, M. Effect of salinity on emergence and on water stress and early seedling growth of sunflower and maize. Agric. Water Manag. 1994. [CrossRef]

98. Almansouri, M.; Kinet, J.M.; Lutts, S. Effect of salt and osmotic stresses on germination in durum wheat (Triticum durum Desf.). Plant Soil 2001. [CrossRef]

99. Zheng, Y.H.; Li, X.; Li, Y.G.; Miao, B.H.; Xu, H.; Simmons, M.; Yang, X.H. Contrasting responses of salinity-stressed salt-tolerant and intolerant winter wheat (Triticum aestivum L.) cultivars to ozone pollution. Plant Physiol. Biochem. 2012. [CrossRef]

100. Kafi, M. The effects of salinity and light on photosynthesis, respiration and chlorophyll fluorescence in salt-tolerant and saltsensitive wheat (Triticum aestivum L.) cultivars. J. Agric. Sci. Technol. 2009, 11, 535-547.

101. Brini, F.; Amara, I.; Feki, K.; Hanin, M.; Khoudi, H.; Masmoudi, K. Physiological and molecular analyses of seedlings of two Tunisian durum wheat (Triticum turgidum L. subsp. Durum [Desf.]) varieties showing contrasting tolerance to salt stress. Acta Physiol. Plant. 2009. [CrossRef]

102. Khan, N.A. NaCl-inhibited chlorophyll synthesis and associated changes in ethylene evolution and antioxidative enzyme activities in wheat. Biol. Plant. 2003. [CrossRef]

103. Heidari, A.; Toorchi, M.; Bandehagh, A.; Shakiba, M. Effect of NaCl Stress on Growth, Water Relations, Organic and Inorganic Osmolytes Accumulation in Sunflower (Helianthus annuus L.) Lines. Univers. J. Environ. Res. Technol. 2011, 1, $351-362$.

104. Liu, J.; Shi, D.C. Photosynthesis, chlorophyll fluorescence, inorganic ion and organic acid accumulations of sunflower in responses to salt and salt-alkaline mixed stress. Photosynthetica 2010. [CrossRef]

105. Barros, C.V.S.D.; Melo, Y.L.; Souza, M. de F.; Silva, D.V.; de Macedo, C.E.C. Sensitivity and biochemical mechanisms of sunflower genotypes exposed to saline and water stress. Acta Physiol. Plant. 2019. [CrossRef]

106. Rivelli, A.R.; de Maria, S.; Pizza, S.; Gherbin, P. Growth and physiological response of hydroponically-grown sunflower as affected by salinity and magnesium levels. J. Plant Nutr. 2010. [CrossRef]

107. Ma, X.; Zhang, J.; Huang, B. Cytokinin-mitigation of salt-induced leaf senescence in perennial ryegrass involving the activation of antioxidant systems and ionic balance. Environ. Exp. Bot. 2016. [CrossRef]

108. Ji, Z.; Camberato, J.J.; Zhang, C.; Jiang, Y. Effects of 6-benzyladenine, g-aminobutyric acid, and nitric oxide on plant growth, photochemical efficiency, and ion accumulation of perennial ryegrass cultivars to salinity stress. HortScience 2019. [CrossRef]

109. Katschnig, D.; Broekman, R.; Rozema, J. Salt tolerance in the halophyte salicornia dolichostachya moss: Growth, morphology and physiology. Environ. Exp. Bot. 2013. [CrossRef]

110. Park, K.W.; An, J.Y.; Lee, H.J.; Son, D.; Sohn, Y.G.; Kim, C.G.; Lee, J.J. The growth and accumulation of osmotic solutes of the halophyte common glasswort (Salicornia europaea) under salinity conditions. J. Aquat. Plant Manag. 2013, 51, $103-108$.

111. Santhanakrishnan, D.; Perumal, R.K.; Kanth, S.V.; Jonnalagadda, R.R.; Bangaru, C. Studies on the physiological and biochemical characteristics of Salicornia brachiata: Influence of saline stress due to soaking wastewater of tannery. Desalin. Water Treat. 2014. [CrossRef]

112. Parida, A.K.; Das, A.B. Salt tolerance and salinity effects on plants: A review. Ecotoxicol. Environ. Saf. 2005, 60, 324-349. [CrossRef]

113. Acosta-Motos, J.R.; Ortuño, M.F.; Bernal-Vicente, A.; Diaz-Vivancos, P.; Sanchez-Blanco, M.J.; Hernandez, J.A. Plant responses to salt stress: Adaptive mechanisms. Agronomy 2017, 7, 18. [CrossRef]

114. Gémes, K.; Kim, Y.J.; Park, K.Y.; Moschou, P.N.; Andronis, E.; Valassaki, C.; Roussis, A.; Roubelakis-Angelakis, K.A. An NADPH-oxidase/polyamine oxidase feedback loop controls oxidative burst under salinity. Plant Physiol. 2016. [CrossRef]

115. Li, Y. Physiological Responses of Tomato Seedlings (Lycopersicon Esculentum) to Salt Stress. Mod. Appl. Sci. 2009. [CrossRef]

116. Chen, Y.E.; Mao, J.J.; Sun, L.Q.; Huang, B.; Ding, C.B.; Gu, Y.; Liao, J.Q.; Hu, C.; Zhang, Z.W.; Yuan, S.; et al. Exogenous melatonin enhances salt stress tolerance in maize seedlings by improving antioxidant and photosynthetic capacity. Physiol. Plant. 2018. [CrossRef] [PubMed]

117. Esfandiari, E.; Gohari, G. Response of ROS-Scavenging systems to salinity stress in two different wheat (Triticum aestivum L.) cultivars. Not. Bot. Horti Agrobot. Cluj-Napoca 2017. [CrossRef]

118. Jain, P.; Bhatla, S.C. Signaling role of phospholipid hydroperoxide glutathione peroxidase (PHGPX) accompanying sensing of $\mathrm{NaCl}$ stress in etiolated sunflower seedling cotyledons. Plant Signal. Behav. 2014. [CrossRef] [PubMed]

119. Kim, Y.; Mun, B.G.; Khan, A.L.; Waqas, M.; Kim, H.H.; Shahzad, R.; Imran, M.; Yun, B.W.; Lee, I.J. Regulation of reactive oxygen and nitrogen species by salicylic acid in rice plants under salinity stress conditions. PLoS ONE 2018. [CrossRef] 
120. Hu, T.; Li, H.Y.; Zhang, X.Z.; Luo, H.J.; Fu, J.M. Toxic effect of $\mathrm{NaCl}$ on ion metabolism, antioxidative enzymes and gene expression of perennial ryegrass. Ecotoxicol. Environ. Saf. 2011. [CrossRef]

121. Parida, A.K.; Jha, B. Antioxidative defense potential to salinity in the euhalophyte Salicornia brachiata. J. Plant Growth Regul. 2010. [CrossRef]

122. Guan, Q.; Takano, T.; Liu, S. Genetic transformation and analysis of rice OsAPx2 gene in Medicago sativa. PLoS ONE 2012. [CrossRef]

123. Poór, P.; Kovács, J.; Borbély, P.; Takács, Z.; Szepesi, Á.; Tari, I. Salt stress-induced production of reactive oxygen- and nitrogen species and cell death in the ethylene receptor mutant Never ripe and wild type tomato roots. Plant Physiol. Biochem. 2015. [CrossRef]

124. Poór, P.; Kovács, J.; Szopkó, D.; Tari, I. Ethylene signaling in salt stress- and salicylic acid-induced programmed cell death in tomato suspension cells. Protoplasma 2013. [CrossRef]

125. Kataria, S.; Baghel, L.; Guruprasad, K.N. Pre-treatment of seeds with static magnetic field improves germination and early growth characteristics under salt stress in maize and soybean. Biocatal. Agric. Biotechnol. 2017. [CrossRef]

126. Hanqing, F.; Yifeng, W.; Hongyu, L.; Rongfang, W.; Kun, S.; Lingyun, J. Salt stress-induced expression of rice AOX1a is mediated through an accumulation of hydrogen peroxide. Biologia (Bratisl) 2010. [CrossRef]

127. Li, J.; Jia, H.; Wang, J.; Cao, Q.; Wen, Z. Hydrogen sulfide is involved in maintaining ion homeostasis via regulating plasma membrane $\mathrm{Na}^{+} / \mathrm{H}^{+}$antiporter system in the hydrogen peroxide-dependent manner in salt-stress Arabidopsis thaliana root. Protoplasma 2014. [CrossRef]

128. Liu, S.G.; Zhu, D.Z.; Chen, G.H.; Gao, X.Q.; Zhang, X.S. Disrupted actin dynamics trigger an increment in the reactive oxygen species levels in the Arabidopsis root under salt stress. Plant Cell Rep. 2012. [CrossRef]

129. Hu, L.; Hu, T.; Zhang, X.; Pang, H.; Fu, J. Exogenous glycine betaine Ameliorates the adverse effect of salt stress on perennial ryegrass. J. Am. Soc. Hortic. Sci. 2012. [CrossRef]

130. Hu, T.; Chen, K.; Hu, L.; Amombo, E.; Fu, J. $\mathrm{H}_{2} \mathrm{O}_{2}$ and $\mathrm{Ca}^{2+}$-based signaling and associated ion accumulation, antioxidant systems and secondary metabolism orchestrate the response to $\mathrm{NaCl}$ stress in perennial ryegrass. Sci. Rep. 2016. [CrossRef]

131. Qiu, Z.B.; Guo, J.L.; Zhu, A.J.; Zhang, L.; Zhang, M.M. Exogenous jasmonic acid can enhance tolerance of wheat seedlings to salt stress. Ecotoxicol. Environ. Saf. 2014. [CrossRef]

132. Sairam, R.K.; Srivastava, G.C.; Agarwal, S.; Meena, R.C. Differences in antioxidant activity in response to salinity stress in tolerant and susceptible wheat genotypes. Biol. Plant. 2005. [CrossRef]

133. Yamane, K.; Mitsuya, S.; Kawasaki, M.; Taniguchi, M.; Miyake, H. Antioxidant capacity and damages caused by salinity stress in apical and basal regions of rice leaf. Plant Prod. Sci. 2009. [CrossRef]

134. AbdElgawad, H.; Zinta, G.; Hegab, M.M.; Pandey, R.; Asard, H.; Abuelsoud, W. High salinity induces different oxidative stress and antioxidant responses in maize seedlings organs. Front. Plant Sci. 2016. [CrossRef]

135. Liu, M.; Yu, H.; Ouyang, B.; Shi, C.; Demidchik, V.; Hao, Z.; Yu, M.; Shabala, S. NADPH oxidases and the evolution of plant salinity tolerance. Plant Cell Environ. 2020. [CrossRef]

136. Qi, Y.C.; Liu, W.Q.; Qiu, L.Y.; Zhang, S.M.; Ma, L.; Zhang, H. Overexpression of glutathione S-transferase gene increases salt tolerance of Arabidopsis. Russ. J. Plant Physiol. 2010. [CrossRef]

137. Li, G.; Peng, X.; Wei, L.; Kang, G. Salicylic acid increases the contents of glutathione and ascorbate and temporally regulates the related gene expression in salt-stressed wheat seedlings. Gene 2013. [CrossRef]

138. Badran, E.G.; Abogadallah, G.M.; Nada, R.M.; Nemat Alla, M.M. Role of glycine in improving the ionic and ROS homeostasis during $\mathrm{NaCl}$ stress in wheat. Protoplasma 2015. [CrossRef]

139. Kaur, H.; Bhatla, S.C. Melatonin and nitric oxide modulate glutathione content and glutathione reductase activity in sunflower seedling cotyledons accompanying salt stress. Nitric Oxide Biol. Chem. 2016. [CrossRef]

140. Mansour, M.M.F. Plasma membrane permeability as an indicator of salt tolerance in plants. Biol. Plant. 2013, 57, 1-10. [CrossRef]

141. Singam, K.; Juntawong, N.; Cha-Um, S.; Kirdmanee, C. Salt stress induced ion accumulation, ion homeostasis, membrane injury and sugar contents in salt-sensitive rice (Oryza sativa L. spp. indica) roots under isoosmotic conditions. Afr. J. Biotechnol. 2011. [CrossRef]

142. Zhang, Z.; Zhang, Q.; Wu, J.; Zheng, X.; Zheng, S.; Sun, X.; Qiu, Q.; Lu, T. Gene Knockout Study Reveals That Cytosolic Ascorbate Peroxidase 2(OsAPX2) Plays a Critical Role in Growth and Reproduction in Rice under Drought, Salt and Cold Stresses. PLoS ONE 2013. [CrossRef]

143. Yarmolinsky, D.; Brychkova, G.; Kurmanbayeva, A.; Bekturova, A.; Ventura, Y.; Khozin-Goldberg, I.; Eppel, A.; Fluhr, R.; Sagi, M. Impairment in sulfite reductase leads to early leaf senescence in tomato plants. Plant Physiol. 2014. [CrossRef]

144. Srivastava, S.; Brychkova, G.; Yarmolinsky, D.; Soltabayeva, A.; Samani, T.; Sagi, M. Aldehyde oxidase 4 plays a critical role in delaying silique senescence by catalyzing aldehyde detoxification. Plant Physiol. 2017. [CrossRef]

145. Gapińska, M.; Skłodowska, M.; Gabara, B. Effect of short- and long-term salinity on the activities of antioxidative enzymes and lipid peroxidation in tomato roots. Acta Physiol. Plant. 2008. [CrossRef]

146. Gong, B.; Wen, D.; VandenLangenberg, K.; Wei, M.; Yang, F.; Shi, Q.; Wang, X. Comparative effects of $\mathrm{NaCl}_{\text {and }} \mathrm{NaHCO}_{3}$ stress on photosynthetic parameters, nutrient metabolism, and the antioxidant system in tomato leaves. Sci. Hortic. (Amst.) 2013. [CrossRef] 
147. Torabi, S.; Niknam, V. Effects of Iso-osmotic Concentrations of $\mathrm{NaCl}$ and Mannitol on some Metabolic Activity in Calluses of Two Salicornia species. Vitr. Cell. Dev. Biol. Plant 2011. [CrossRef]

148. Wang, Y.; Ying, Y.; Chen, J.; Wang, X. Transgenic Arabidopsis overexpressing Mn-SOD enhanced salt-tolerance. Plant Sci. 2004. [CrossRef]

149. El-Hendawy, S.; Al-Suhaibani, N.; Hassan, W.; Tahir, M.; Schmidhalter, U. Hyperspectral reflectance sensing to assess the growth and photosynthetic properties of wheat cultivars exposed to different irrigation rates in an irrigated arid region. PLOS ONE 2017. [CrossRef]

150. Awlia, M.; Alshareef, N.; Saber, N.; Korte, A.; Oakey, H.; Panzarová, K.; Trtílek, M.; Negrão, S.; Tester, M.; Julkowska, M.M. Genetic mapping of the early responses to salt stress in Arabidopsis thaliana. bioRxiv Plant Biol. 2020. [CrossRef]

151. Gong, Q.; Li, P.; Ma, S.; Indu Rupassara, S.; Bohnert, H.J. Salinity stress adaptation competence in the extremophile Thellungiella halophila in comparison with its relative Arabidopsis thaliana. Plant J. 2005. [CrossRef]

152. Goyal, E.; Amit, S.K.; Singh, R.S.; Mahato, A.K.; Chand, S.; Kanika, K. Transcriptome profiling of the salt-stress response in Triticum aestivum cv. Kharchia Local. Sci. Rep. 2016. [CrossRef]

153. Liu, J. The Arabidopsis thaliana $\mathrm{SOS}_{2}$ gene encodes a protein kinase that is required for salt tolerance. Proc. Natl. Acad. Sci. USA 2000. [CrossRef]

154. Shabala, S.; Wu, H.; Bose, J. Salt stress sensing and early signalling events in plant roots: Current knowledge and hypothesis. Plant Sci. 2015, 241, 109-119. [CrossRef]

155. Sagor, G.H.M.; Zhang, S.; Kojima, S.; Simm, S.; Berberich, T.; Kusano, T. Reducing cytoplasmic polyamine oxidase activity in Arabidopsis increases salt and drought tolerance by reducing reactive oxygen species production and increasing defense gene expression. Front. Plant Sci. 2016. [CrossRef]

156. Formentin, E.; Sudiro, C.; Perin, G.; Riccadonna, S.; Barizza, E.; Baldoni, E.; Lavezzo, E.; Stevanato, P.; Sacchi, G.A.; Fontana, P.; et al. Transcriptome and cell physiological analyses in different rice cultivars provide new insights into adaptive and salinity stress responses. Front. Plant Sci. 2018. [CrossRef]

157. Liu, C.; Mao, B.; Ou, S.; Wang, W.; Liu, L.; Wu, Y.; Chu, C.; Wang, X. OsbZIP71, a bZIP transcription factor, confers salinity and drought tolerance in rice. Plant Mol. Biol. 2014. [CrossRef] [PubMed]

158. Wei, Q.; Liu, Y.; Zhou, G.; Li, Q.; Yang, C.; Peng, S. Overexpression of CsCLCc, a Chloride Channel Gene from Poncirus trifoliata, Enhances Salt Tolerance in Arabidopsis. Plant Mol. Biol. Rep. 2013. [CrossRef]

159. Seki, M.; Narusaka, M.; Ishida, J.; Nanjo, T.; Fujita, M.; Oono, Y.; Kamiya, A.; Nakajima, M.; Enju, A.; Sakurai, T.; et al. Monitoring the expression profiles of 7000 Arabidopsis genes under drought, cold and high-salinity stresses using a full-length cDNA microarray. Plant J. 2002. [CrossRef] [PubMed]

160. Xiong, H.; Guo, H.; Xie, Y.; Zhao, L.; Gu, J.; Zhao, S.; Li, J.; Liu, L. RNAseq analysis reveals pathways and candidate genes associated with salinity tolerance in a spaceflight-induced wheat mutant. Sci. Rep. 2017. [CrossRef] [PubMed]

161. Li, H.; Hu, T.; Fu, J. Identification of genes associated with adaptation to $\mathrm{NaCl}$ toxicity in perennial ryegrass (Lolium perenne $\mathrm{L}$.). Ecotoxicol. Environ. Saf. 2012. [CrossRef]

162. Jiang, Y.; Deyholos, M.K. Comprehensive transcriptional profiling of NaCl-stressed Arabidopsis roots reveals novel classes of responsive genes. BMC Plant Biol. 2006. [CrossRef]

163. Jiang, Y.; Yang, B.; Harris, N.S.; Deyholos, M.K. Comparative proteomic analysis of $\mathrm{NaCl}$ stress-responsive proteins in Arabidopsis roots. J. Exp. Bot. 2007. [CrossRef]

164. Chookhampaeng, S.; Pattanagul, W.; Theerakulpisut, P. Effects of salinity on growth, activity of antioxidant enzymes and sucrose content in tomato (Lycopersicon esculentum Mill.) at the reproductive stage. Sci. Asia 2008. [CrossRef]

165. Hu, L.; Li, H.; Pang, H.; Fu, J. Responses of antioxidant gene, protein and enzymes to salinity stress in two genotypes of perennial ryegrass (Lolium perenne) differing in salt tolerance. J. Plant Physiol. 2012. [CrossRef]

166. Zarza, X.; Atanasov, K.E.; Marco, F.; Arbona, V.; Carrasco, P.; Kopka, J.; Fotopoulos, V.; Munnik, T.; Gómez-Cadenas, A.; Tiburcio, A.F.; et al. Polyamine oxidase 5 loss-of-function mutations in Arabidopsis thaliana trigger metabolic and transcriptional reprogramming and promote salt stress tolerance. Plant Cell Environ. 2017. [CrossRef] [PubMed]

167. Nounjan, N.; Nghia, P.T.; Theerakulpisut, P. Exogenous proline and trehalose promote recovery of rice seedlings from salt-stress and differentially modulate antioxidant enzymes and expression of related genes. J. Plant Physiol. 2012. [CrossRef] [PubMed]

168. Rivero, R.M.; Mestre, T.C.; Mittler, R.; Rubio, F.; Garcia-Sanchez, F.; Martinez, V. The combined effect of salinity and heat reveals a specific physiological, biochemical and molecular response in tomato plants. Plant Cell Environ. 2014. [CrossRef] [PubMed]

169. Ma, L.; Zhou, E.; Gao, L.; Mao, X.; Zhou, R.; Jia, J. Isolation, expression analysis and chromosomal location of P5CR gene in common wheat (Triticum aestivum L.). S. Afr. J. Bot. 2008. [CrossRef]

170. Li, H.; Guo, H.; Zhang, X.; Fu, J. Expression profiles of Pr5CS1 and Pr5CS2 genes and proline accumulation under salinity stress in perennial ryegrass (Lolium perenne L.). Plant Breed. 2014. [CrossRef]

171. Cheng, L.; Li, X.; Huang, X.; Ma, T.; Liang, Y.; Ma, X.; Peng, X.; Jia, J.; Chen, S.; Chen, Y.; et al. Overexpression of sheepgrass R1-MYB transcription factor LcMYB1 confers salt tolerance in transgenic Arabidopsis. Plant Physiol. Biochem. 2013. [CrossRef]

172. Thomas, S.; Krishna, G.K.; Yadav, P.; Pal, M. Cloning and abiotic stress responsive expression analysis of arginine decarboxylase genes in contrasting rice genotypes. Indian J. Genet. Plant Breed. 2019. [CrossRef] 
173. Fan, P.; Nie, L.; Jiang, P.; Feng, J.; Lv, S.; Chen, X.; Bao, H.; Guo, J.; Tai, F.; Wang, J.; et al. Transcriptome analysis of salicornia europaea under saline conditions revealed the adaptive primary metabolic pathways as early events to facilitate salt adaptation. PLoS ONE 2013. [CrossRef]

174. Balazadeh, S.; Siddiqui, H.; Allu, A.D.; Matallana-Ramirez, L.P.; Caldana, C.; Mehrnia, M.; Zanor, M.I.; Köhler, B.; Mueller-Roeber, B. A gene regulatory network controlled by the NAC transcription factor ANAC092/AtNAC2/ORE1 during salt-promoted senescence. Plant J. 2010. [CrossRef]

175. Chen, X.; Wang, Y.; Lv, B.; Li, J.; Luo, L.; Lu, S.; Zhang, X.; Ma, H.; Ming, F. The NAC family transcription factor OsNAP confers abiotic stress response through the ABA pathway. Plant Cell Physiol. 2014. [CrossRef]

176. Balazadeh, S.; Wu, A.; Mueller-Roeber, B. Salt-triggered expression of the ANAC092-dependent senescence regulon in Arabidopsis thaliana. Plant Signal. Behav. 2010. [CrossRef] [PubMed]

177. Allu, A.D.; Soja, A.M.; Wu, A.; Szymanski, J.; Balazadeh, S. Salt stress and senescence: Identification of cross-talk regulatory components. J. Exp. Bot. 2014. [CrossRef] [PubMed]

178. Wang, H.; Zhang, M.; Guo, R.; Shi, D.; Liu, B.; Lin, X.; Yang, C. Effects of salt stress on ion balance and nitrogen metabolism of old and young leaves in rice (Oryza sativa L.). BMC Plant Biol. 2012. [CrossRef] [PubMed]

179. Bailey-Serres, J.; Mittler, R. The roles of reactive oxygen species in plant cells. Plant Physiol. 2006. [CrossRef] [PubMed]

180. Vestergaard, C.L.; Flyvbjerg, H.; Møller, I.M. Intracellular signaling by diffusion: Can waves of hydrogen peroxide transmit intracellular information in plant cells? Front. Plant Sci. 2012. [CrossRef]

181. Ortega-Villasante, C.; Burén, S.; Blázquez-Castro, A.; Barón-Sola, Á.; Hernández, L.E. Fluorescent in vivo imaging of reactive oxygen species and redox potential in plants. Free Radic. Biol. Med. 2018, 122, 202-220. [CrossRef]

182. Miller, G.; Suzuki, N.; Ciftci-Yilmaz, S.; Mittler, R. Reactive oxygen species homeostasis and signalling during drought and salinity stresses. Plant Cell Environ. 2010. [CrossRef]

183. Jiang, K.; Schwarzer, C.; Lally, E.; Zhang, S.; Ruzin, S.; Machen, T.; Remington, S.J.; Feldman, L. Expression and characterization of a redox-sensing green fluorescent protein (reduction-oxidation-sensitive green fluorescent protein) in Arabidopsis. Plant Physiol. 2006. [CrossRef]

184. Meyer, A.J.; Brach, T.; Marty, L.; Kreye, S.; Rouhier, N.; Jacquot, J.P.; Hell, R. Redox-sensitive GFP in Arabidopsis thaliana is a quantitative biosensor for the redox potential of the cellular glutathione redox buffer. Plant J. 2007. [CrossRef]

185. Morgan, M.J.; Lehmann, M.; Schwarzländer, M.; Baxter, C.J.; Sienkiewicz-Porzucek, A.; Williams, T.C.R.; Schauer, N.; Fernie, A.R.; Fricker, M.D.; Ratcliffe, R.G.; et al. Decrease in manganese superoxide dismutase leads to reduced root growth and affects tricarboxylic acid cycle flux and mitochondrial redox homeostasis. Plant Physiol. 2008. [CrossRef]

186. Shao, N.; Krieger-Liszkay, A.; Schroda, M.; Beck, C.F. A reporter system for the individual detection of hydrogen peroxide and singlet oxygen: Its use for the assay of reactive oxygen species produced in vivo. Plant J. 2007. [CrossRef] [PubMed]

187. Puniran-Hartley, N.; Hartley, J.; Shabala, L.; Shabala, S. Salinity-induced accumulation of organic osmolytes in barley and wheat leaves correlates with increased oxidative stress tolerance: In planta evidence for cross-tolerance. Plant Physiol. Biochem. 2014 [CrossRef] [PubMed]

188. Luo, L.; Zhang, P.; Zhu, R.; Fu, J.; Su, J.; Zheng, J.; Wang, Z.; Wang, D.; Gong, Q. Autophagy is rapidly induced by salt stress and is required for salt tolerance in Arabidopsis. Front. Plant Sci. 2017. [CrossRef] [PubMed]

189. Wei, W.; Bilsborrow, P.E.; Hooley, P.; Fincham, D.A.; Lombi, E.; Forster, B.P. Salinity induced differences in growth, ion distribution and partitioning in barley between the cultivar Maythorpe and its derived mutant Golden Promise. Plant Soil 2003. [CrossRef]

190. Hu, Y.; Burucs, Z.; Schmidhalter, U. Effect of foliar fertilization application on the growth and mineral nutrient content of maize seedlings under drought and salinity. Soil Sci. Plant Nutr. 2008. [CrossRef]

191. Ebrahimi, R.; Bhatla, S.C. Effect of sodium chloride levels on growth, water status, uptake, transport, and accumulation pattern of sodium and chloride ions in young sunflower plants. Commun. Soil Sci. Plant Anal. 2011. [CrossRef]

192. Vieira Santos, C.L.; Campos, A.; Azevedo, H.; Caldeira, G. In situ and in vitro senescence induced by KCI stress: Nutritional imbalance, lipid peroxidation and antioxidant metabolism. J. Exp. Bot. 2001. [CrossRef]

193. Hajlaoui, H.; Ayeb, N.E.; Garrec, J.P.; Denden, M. Differential effects of salt stress on osmotic adjustment and solutes allocation on the basis of root and leaf tissue senescence of two silage maize (Zea mays L.) varieties. Ind. Crops Prod. 2010. [CrossRef]

194. Cuin, T.A.; Parsons, D.; Shabala, S. Wheat cultivars can be screened for $\mathrm{NaCl}$ salinity tolerance by measuring leaf chlorophyll content and shoot sap potassium. Funct. Plant Biol. 2010. [CrossRef]

195. Wimmer, M.A.; Mühling, K.H.; Läuchli, A.; Brown, P.H.; Goldbach, H.E. The interaction between salinity and boron toxicity affects the subcellular distribution of ions and proteins in wheat leaves. Plant Cell Environ. 2003. [CrossRef]

196. Singh, A.K.; Ganapathysubramanian, B.; Sarkar, S.; Singh, A. Deep Learning for Plant Stress Phenotyping: Trends and Future Perspectives. Trends Plant Sci. 2018, 23, 883-898. [CrossRef] [PubMed]

197. Douarre, C.; Schielein, R.; Frindel, C.; Gerth, S.; Rousseau, D. Deep learning based root-soil segmentation from X-ray tomography. bioRxiv 2016. [CrossRef]

198. Akar, Ö.; Güngör, O. Classification of multispectral images using Random Forest algorithm. J. Geod. Geoinf. 2012. [CrossRef]

199. Ho Tong Minh, D.; Ienco, D.; Gaetano, R.; Lalande, N.; Ndikumana, E.; Osman, F.; Maurel, P. Deep Recurrent Neural Networks for Winter Vegetation Quality Mapping via Multitemporal SAR Sentinel-1. IEEE Geosci. Remote Sens. Lett. 2018. [CrossRef] 
200. Feng, X.; Yu, C.; Chen, Y.; Peng, J.; Ye, L.; Shen, T.; Wen, H.; He, Y. Non-destructive determination of shikimic acid concentration in transgenic maize exhibiting glyphosate tolerance using chlorophyll fluorescence and hyperspectral imaging. Front. Plant Sci. 2018. [CrossRef]

201. Biju, S.; Fuentes, S.; Gupta, D. The use of infrared thermal imaging as a non-destructive screening tool for identifying droughttolerant lentil genotypes. Plant Physiol. Biochem. 2018. [CrossRef]

202. Chen, D.; Shi, R.; Pape, J.M.; Neumann, K.; Arend, D.; Graner, A.; Chen, M.; Klukas, C. Predicting plant biomass accumulation from image-derived parameters. Gigascience 2018. [CrossRef]

203. Alhnaity, B.; Pearson, S.; Leontidis, G.; Kollias, S. Using deep learning to predict plant growth and yield in greenhouse environments. arXiv 2019, arXiv:1907.00624

204. Altangerel, N.; Ariunbold, G.O.; Gorman, C.; Alkahtani, M.H.; Borrego, E.J.; Bohlmeyer, D.; Hemmer, P.; Kolomiets, M.V.; Yuan, J.S.; Scully, M.O. In vivo diagnostics of early abiotic plant stress response via Raman spectroscopy. Proc. Natl. Acad. Sci. USA 2017. [CrossRef]

205. Gao, G.; Tester, M.A.; Julkowska, M.M. The Use of High-Throughput Phenotyping for Assessment of Heat Stress-Induced Changes in Arabidopsis. Plant Phenomics 2020. [CrossRef]

206. Chiu, W.L.; Niwa, Y.; Zeng, W.; Hirano, T.; Kobayashi, H.; Sheen, J. Engineered GFP as a vital reporter in plants. Curr. Biol. 1996. [CrossRef] 